\title{
Geochemical insights from clinopyroxene phenocrysts into the magma evolution of an alkaline magmatic system from the Sanshui Basin, South China
}

\author{
Peijia Chen ${ }^{1}$, Nianqiao Fang ${ }^{1, *}$ and Xiaobo Yuan ${ }^{1,2}$ \\ 1 School of Ocean Science, China University of Geoscience (Beijing), Beijing 100083, China; \\ 3011180003@cugb.edu.cn (P.C); fangnq@cugb.edu.cn (N.F.); yuanxiaobo2011@163.com \\ 2 Marine Science Research Center, Hebei Normal University of Science \& Technology, Qinhuangdao 066004, \\ China; \\ * Correspondence: fangnq@cugb.edu.cn
}

\begin{abstract}
The Sanshui Basin (SSB) is located at the northern continental margin of the South China Sea and characterized by a continental rift basin. The bimodal volcanic rocks in SSB record the early Cenozoic magmatic activity in the South China Block, on the magmatic evolution process of bimodal volcanic rocks are poorly understood. Clinopyroxenes in bimodal volcanic rocks in the SSB provide an opportunity to investigate the magma process during magma ascent. We classified nine types of clinopyroxene phenocrysts according to the different compositions and textures types in cogenetic basalt-trachyandesite-comenditic trachyte, the composition of unzoned clinopyroxene have an evolution sequence of diopside- hedenbergite- aegirine with the decrease of $\mathrm{Mg}^{\sharp}$, and the trace element contents of unzoned clinopyroxenes also increase systematically during magma evolution, indicating that the genesis of clinopyroxene dominated by fractional crystallization in a closed magma system; however, the clinopyroxenes with reverse zoning and multiple zoning record the process of magma mixing and recharge indicating an open magma system. Whilst fractional crystallization is the dominated process, magma mixing, recharge, and crystal settling complicate magma evolution. Thermobarometric calculations show that clinopyroxene phenocrysts in bimodal volcanic rocks of SSB are distributed in the whole crust during magma ascent. We have established a magma plumbing system, which provides a new constrain for the complex magmatic evolution history in the SSB by detailed mineral-scale analysis.
\end{abstract}

Keywords: Sanshui Basin, Clinopyroxene phenocryst, Thermobarometry, Magma mixing, Fractional crystallization

\section{Introduction}

As the product of volcanic eruption, volcanic rocks record the results of magmatism. The study of volcanic rocks can help us investigate the deep magma process and its evolutionary history. However, the magma chamber process such as magma mixing, recharge, crystal mush remobilization, fractional crystallization, and assimilation complicates the magma evolution process and may trigger volcanic eruption [1-3], these characteristics are not obvious only taking the whole volcanic rock analysis if the mixing process is efficient [2,4-6]. When magma ascends from deep magma depths to shallow reservoir, the changes of physical and chemical conditions affect the texture and composition of minerals and are recorded and preserved in minerals $[7,8]$.

Clinopyroxene is an important rock-forming mineral in volcanic rocks, due to its wide crystallization range. The textural characteristics and composition zoning of clinopyroxene record the magmatic crystallization history and constrain the magma storage conditions, which provides an opportunity to investigate the magma process during magma ascent $[2,9,10]$. Clinopyroxene has been studied worldwide for a long time $[2,7,11$ - 
20], The mineral scales study of clinopyroxene with different textures and compositions can be used to distinguish open- and closed- magma systems and provide a good indicator to unravel the evolution of magma system and establish magma plumbing system $[1,2,11]$.

The SSB is one of the continental rift basins distributed along with NEE trend in the northern continental margin of the South China Sea. The bimodal volcanic rocks consist of alkaline basalt and peralkaline felsic rocks in the SSB record the early Cenozoic magmatism in South China Block and represent the beginning of the large-scale extensional event and mantle upwelling in South China Block [21]. The widely distributed bimodal volcanic rocks of SSB are also noteworthy characteristics compared with other basins. Previous studies have shown that basalt is mantle-derived, and then forms peralkaline felsic volcanic rocks by fractional crystallization at the crust depths [22,23], however, the magma process of bimodal volcanic rock in the crust is not yet clear. Zhang [24] studied tholeiitic compositional clinopyroxene in alkaline basalt of the SSB, but the more abundance of clinopyroxene in basalts felsic end-member has less research. The bimodal volcanic rocks record the evolution and magma ascent history from deep depth, and the magma process complicates magma plumbing system beneath the SSB. In this paper, we first studied the major and trace element characteristics of clinopyroxene with different textures and composition characteristics in the cogenetic magmatic sequence consist of basalt-trachyandesite-comenditic trachyte in the SSB. Combined with the whole rock geochemical simulation of fractional crystallization, we establish an appropriate magma plumbing system through thermobarometeric calculation to deeply understand the magma process in the SSB and reveals the tectonic evolution of the northern continental margin of the South China Sea in the early Cenozoic.

\section{Geologic setting}

The SSB is located in the northern continental margin of the South China Sea, and is a sedimentaric-volcanic basin with continental rift characteristics developed in the Late Cretaceous to Late Eocene [25]. Constrained by the NE-trending Sihui-Wuchuan Fault, NW-trending Gangyao-Shawan Fault, and Xijiang Fault, the SSB has a rhomboid geometry with a north-south-trending eruption axis, cover an area of about $3300 \mathrm{~km}^{2}[25,26]$. The crustal thickness of the SSB $(27 \sim 28 \mathrm{~km})$ is significantly thinner than the Wuyi-Nanling fold zone in the north $(30 \sim 33 \mathrm{~km})$ and have high Bouguer gravity anomaly, due to crustal extension $[25,27]$.

During the contemporaneous stratigraphic deposition in the SSB, there was extensive bimodal volcanic activity, which was mainly in 60-38 Ma [28]. Although there are rare on the surface outcrops, according to the drilling data, there are more than $1000 \mathrm{~m}$ of volcanic rocks beneath the SSB [26]. Basaltic basalts are distributed in Zidong, Jiangbian, Wangjiegang, JiliXu, and Shitoucun in the center of the basin (Fig. 1). The age ranges from 60-43 Ma and have peak period of $\sim 57 \mathrm{Ma}$. The basalt is mainly olivine basalt and olivine tholeiite with OIB characteristics [28,29]. Compared to the scattered distribution of basalt, felsic volcanic rocks are concentratively distributed Shiling - Zoumaying in the north and Xiqiao Mountain in the south. The age ranges from 56-38 Ma, and has a peak period of 55$56 \mathrm{Ma}$. The geochemical characteristics of silicic volcanic rocks are weakly peralkaline, comenditic trachyte, comendite, and pantellerite. These peralkaline felsic volcanic rocks have the characteristics of A1 type rhyolite [28]. Trachyandesite is exposed near the southern Xiqiao Mountain, and its distribution range is very limited.

The basalt and peralkaline felsic volcanic rocks in the SSB have similar trace elements and REE distribution patterns and have similar $\varepsilon \mathrm{Nd}(\mathrm{t})$ isotopic composition characteristics, so they are considered to be the results of cogenetic magmatic evolution: mantle-derived basalts form peralkaline felsic volcanic rocks through long-term fractional crystallization at the shallow crust [22,23]. 


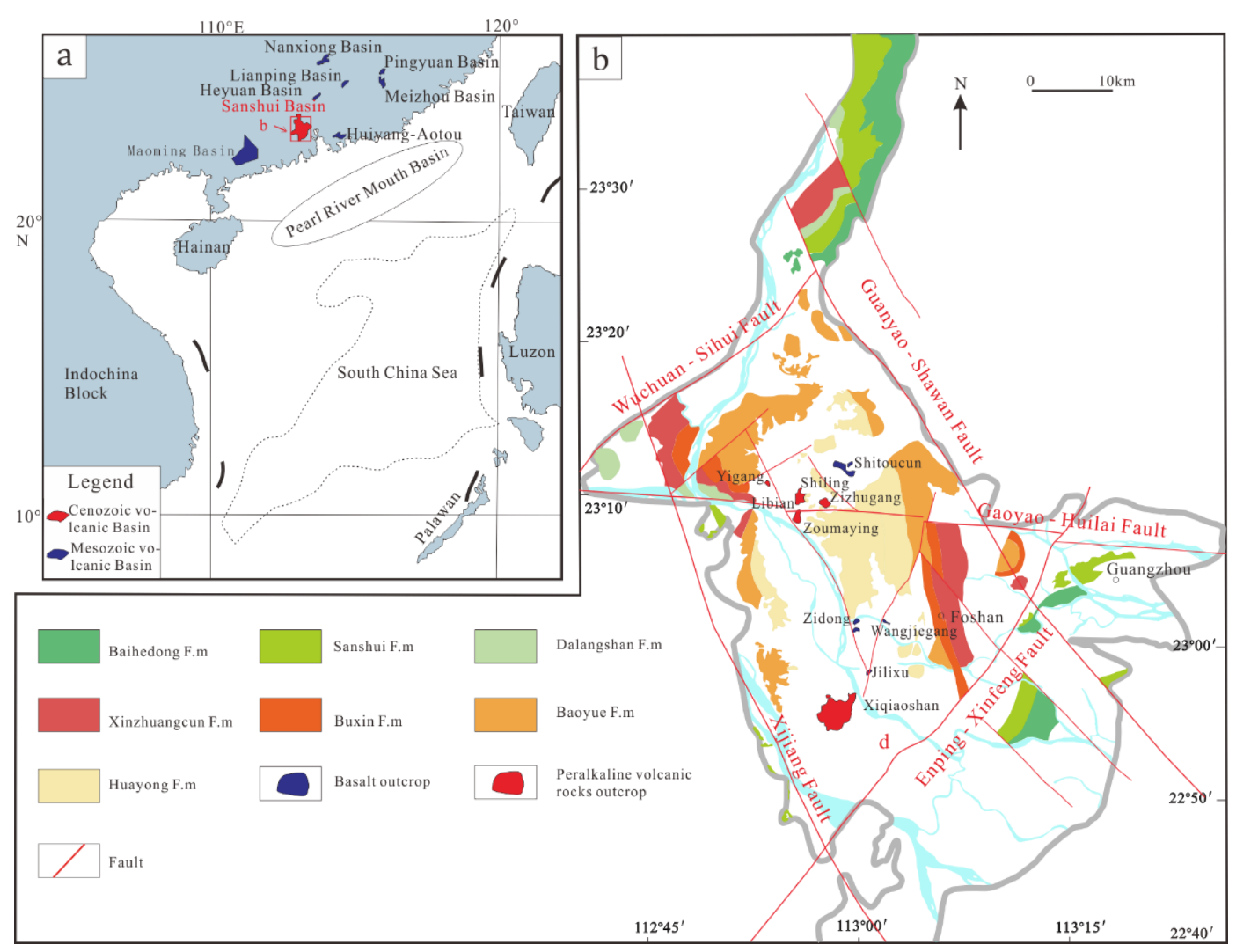

Figure 1. (a) Distribution map of volcanic basins to the northern continental margin of the South China Sea. (b) Geological map of the SSB.

\section{Materials and Methods}

Sample were taken from the SSB. After examining the textures and petrography of the volcanic rocks under a microscope at the School of Ocean Science of China University of Geosciences Beijing (CUGB), we used polished sections of these volcanic rocks to conduct EPMA and in-situ trace element analyses of the clinopyroxene phenocrysts.

The major elements were analyzed with an electronic microprobe (EMPA)-1600 Superprobe at the State Key Laboratory of Geological Process and Mineral Resources of CUGB. $15 \mathrm{kV}$ accelerating voltage, $10 \mathrm{nA}$ beam current, and $5 \mathrm{~mm}$ beam diameter were used for clinopyroxene analysis. Natural minerals and synthetic pure oxides (SPI Company of America) were used as standards. The standards used for calibration of the clinopyroxene analyses were olivine (for $\mathrm{Si}$ and $\mathrm{Mg}$ ), rutile (for $\mathrm{Ti}$ ), albite (for $\mathrm{Al}, \mathrm{Na}$, and $\mathrm{K}$ ), garnet (for $\mathrm{Fe}$ ), rhodonite (for $\mathrm{Mn}$ ), diopside (for $\mathrm{Ca}$ ) and chromite (for $\mathrm{Cr}$ ). The precision was better than $1 \mathrm{wt} \%$ for element oxides.

Trace element compositions of clinopyroxene were performed on a Bruker M90 ICPMS equipped with a RESOlution S-155 $195 \mathrm{~nm}$ excimer laser-ablation system at the Institute of Mineral Resources, Chinese Academy of Geological Sciences, Beijing (CAGS). During the clinopyroxene measurements, helium gas was applied as a carrier gas, which was mixed with argon as the make-up gas to decrease the detection limit and improve the precision, analysis incorporated a background acquisition of approximately $15 \mathrm{~s}$ (gas blank), followed by $45 \mathrm{~s}$ of data acquisition from the sample. Detailed information regarding the operation steps of the LA -ICP-MS was followed by Liu [30]. Element contents were calibrated against multiple-reference materials (BCR-2G, NIST 610, and GSE-1G) and used $\mathrm{Ca}$ as an internal standard measured with an electron microprobe [31]. The preferred values of element concentrations for these USGS glasses are from the GeoReM database (http://georem.mpch-mainz.gwdg.de/). Off-line selection and integration of background and analyte signals, time-drift correction, and quantitative calibration were performed by ICPMSDataCal 10.8 [30,31]. The analysis of most of the elements has an accuracy of less than $5 \%$ and a precision greater than $10 \%$. 


\section{4. $\quad$ Petrography and Mineralogy}

\subsection{Characteristics of petrography}

Basalts exhibit a porphyritic seriate texture (porphyritic index, P.I. $=25-35 \%$ ) with olivine $(\sim 5 \%)$, clinopyroxene $(\sim 7 \%)$, and plagioclase $(\sim 18 \%)$ phenocrysts, set in a microcrystalline groundmass of the same phases plus Ti-Fe oxides and apatite as accessory minerals. Olivine (Fo61 to Fo83) phenocrysts are usually serpentinized along the rim and crack, clinopyroxene phenocrysts are usually euhedral and fresh, and plagioclase (An44-An76) is euhedral - subhedral tabular.
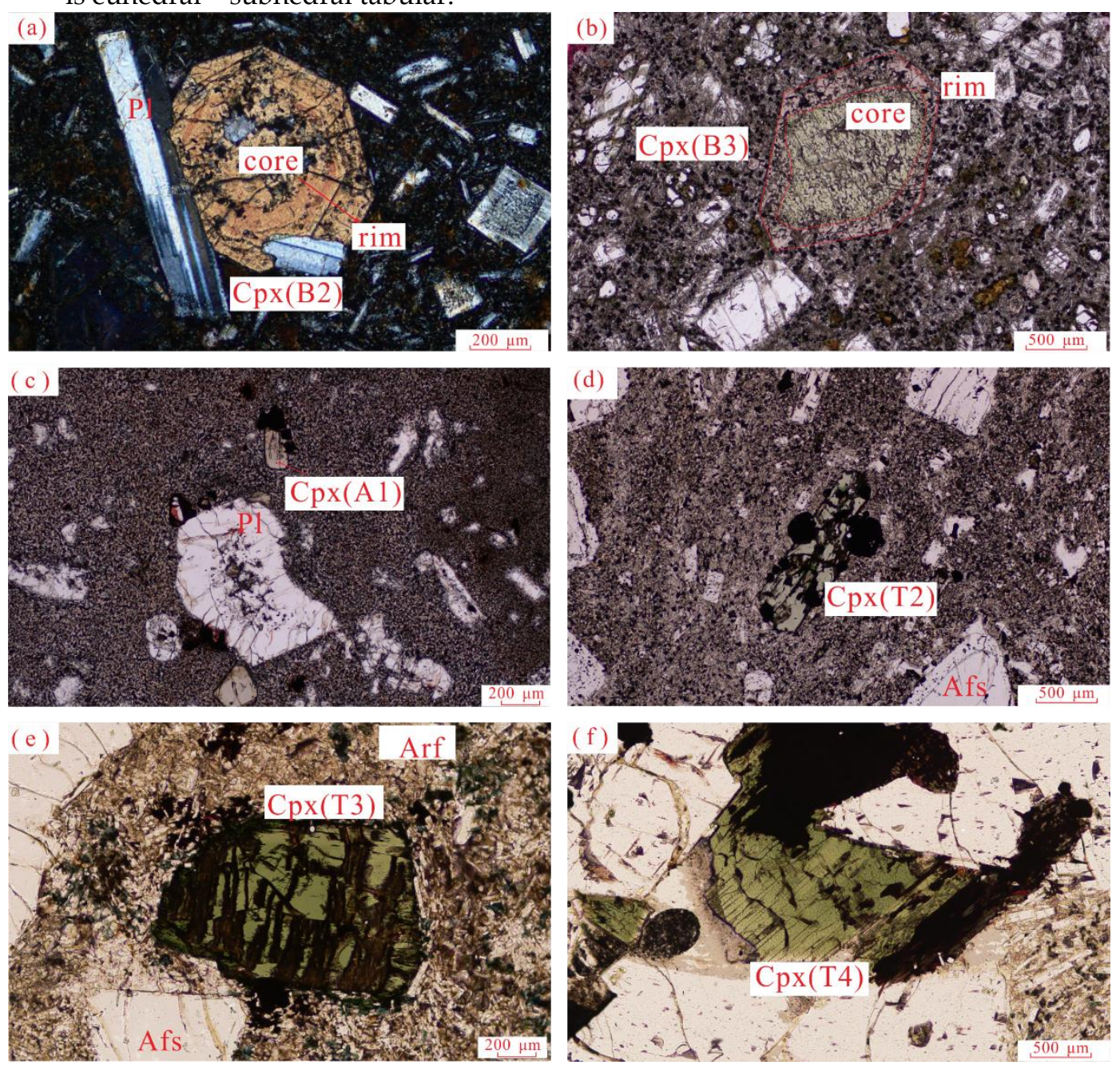

Figure 2. characteristics of representative clinopyroxene in bimodal volcanic rocks in the SSB. (a) B2 type clinopyroxene phenocryst and plagioclase phenocryst in basalt, zoning texture can be observed in clinopyroxene, 18ss082-1; (b) B3 clinopyroxene phenocryst in basalt, with green core and light yellow rim, 17ss063-1; (c) A1 type clinopyroxene phenocryst in trachyandesite, 18ss014-1; (d) T2 type clinopyroxene phenocryst and coexisted titan-magnetite in comenditic trachyte, 19ss027-1; (e) T3 clinopyroxene phenocryst in comenditic trachyte, and amounts of arfvedsointe distributed in the groundmass, 17ss054-1; (f) T4 type clinopyroxene coexist with alkali feldspar in comenditic trachyte, 14ss003-5. Cpx=clinopyroxene, $\mathrm{Pl}=$ plagioclase, Afs=alkali feldspar, Arf= arfvedsonite.

Trachyandsite exhibit a porphyritic seriate texture (P.I.= 10-12\%) with olivine ( 1\%), clinopyroxene $(\sim 3 \%)$, and plagioclase $(\sim 7 \%)$ phenocrysts and lesser amounts of K-feldspar, set in a microcrystalline groundmass of the same phases plus Ti-Fe oxides and apatite as accessory minerals.

The clinopyroxene phenocrysts of peralkaline felsic volcanic rocks occur only in part of comenditic trachyte. comenditic trachyte exhibit a porphyritic seriate texture (P.I.= 8$15 \%)$ with mainly alkaline feldspar ( $\sim 6-13 \%)$ phenocrysts and lesser amounts of clinopyroxene $(\sim 0-2 \%)$, arfvedsonite, and Ti-Fe oxides phenocrysts, set in a microcrystalline groundmass of the same phases with accessory minerals such as haleniusite, apatite, 
monazite, pyrochlore, and zircon. The phenocrysts of pantellerite are less (P.I. $=2-5 \%)$ and are mostly all alkaline feldspar.

\subsection{Characteristics of clinopyroxene}

Clinopyroxene phenocrysts are commonly observed in basalt, trachyandesite, and comenditic trachyte, but have not been found in comendite and pantellerite with more evolution. Clinopyroxene phenocrysts are euhedral-subhedral columnar, and the size is between $0.25-4 \mathrm{~mm}$. Clinopyroxene can be classified into 9 types according to their composition and structural characteristics in the bimodal volcanic rocks from the SSB. Specific classification and characteristics of clinopyroxenes are shown in Table. 1, Fig. 2 and Fig. 3.

Table 1. Summary of the clinopyroxene textures, zoning, and chemical characteristics in the bimodal volcanic rocks.

\begin{tabular}{|c|c|c|c|c|}
\hline Type & Zoning & Texture & Abundance & Description \\
\hline B1 & Unzone & & 93 & $\begin{array}{c}\text { Light yellow, Uncolor; No discernible zoning or Mg\# } \\
\text { variations }<2\end{array}$ \\
\hline B2 & Normal & & 5 & $\begin{array}{l}\text { Light yellow, Uncolor; gradational normal zoning } \\
\text { with Mg\# decrease from core to rim }\end{array}$ \\
\hline B3 & Reverse & & 1 & $\begin{array}{l}\text { Light green core with yellow rim, concentric zoning } \\
\text { or patchy zoning. Mg\# variations are usually }>15\end{array}$ \\
\hline B4 & Multiple & & 1 & $\begin{array}{l}\text { Light yellow; coarse banding zoning }(100 \mathrm{~mm}), \mathrm{Mg} \# \\
\text { variations are usually } \sim 10\end{array}$ \\
\hline A1 & Unzone & & 100 & Light yellow, No discernible zoning, $\mathrm{Mg}^{\sharp}=64$ \\
\hline $\mathrm{T} 1$ & Unzone & & 1 & Light yellow, No discernible zoning, $\mathrm{Mg}^{\sharp}=75$ \\
\hline $\mathrm{T} 2$ & Unzone & & 65 & $\begin{array}{c}\text { Light green, No discernible zoning, } \mathrm{Mg}^{\sharp} \text { variations are } \\
\text { scattered }\end{array}$ \\
\hline T3 & Unzone & & 33 & Green, No discernible zoning, $\mathrm{Mg}^{\sharp}<10$ \\
\hline $\mathrm{T} 4$ & Unzone & & 1 & Dark green, No discernible zoning, $\mathrm{Mg}^{\sharp}<1$ \\
\hline
\end{tabular}

\section{Results}

The major and trace elements of clinopyroxene for bimodal volcanic rocks in the SSB are listed in Table S1 and Table. S2. According to the Wo-En-Fs diagram (Fig. 4a), clinopyroxenes in basalt and trachyandesite are augite-diopside; T1 type clinopyroxenes are diopside, which have similar compositions to that clinopyroxenes in basalt; T2 type clinopyroxenes are diopside to hedenbergite; $\mathrm{T} 3$ type clinopyroxenes are hedenbergite; and T4 type clinopyroxenes are aegirine. The same evolution trend can also be observed in the Aeg-Di-Hd diagram (Fig. 4b), the primitive diopside component of basalt to hedenbergite in comenditic trachyte, the continuous evolution component gradually changes to aegirine, this evolution trend can also be observed in other alkaline volcanic rock series $[1$, 33]. In the Hark diagram (Fig. 5), it can be seen that the contents of $\mathrm{TiO}_{2}, \mathrm{Al}_{2} \mathrm{O}_{3}$, and $\mathrm{Cr}_{2} \mathrm{O}_{3}$ are positively correlated with $\mathrm{Mg}^{*}$ and the contents of $\mathrm{Na}_{2} \mathrm{O}, \mathrm{Mn}_{2} \mathrm{O}, \mathrm{Eu} / \mathrm{Eu}^{*}$ and $\Sigma R E E$ are negatively correlated with $\mathrm{Mg}^{*}\left(\mathrm{Mg}^{*}=100 \times \mathrm{Mg} /(\mathrm{Mg}+\mathrm{Fe})\right.$, where $\mathrm{Fe}$ is the total iron content), and the continuous distribution of clinopyroxene $\mathrm{Mg}^{\#}$ indicates that the bimodal volcanic rocks in the SSB are cogenetic. 


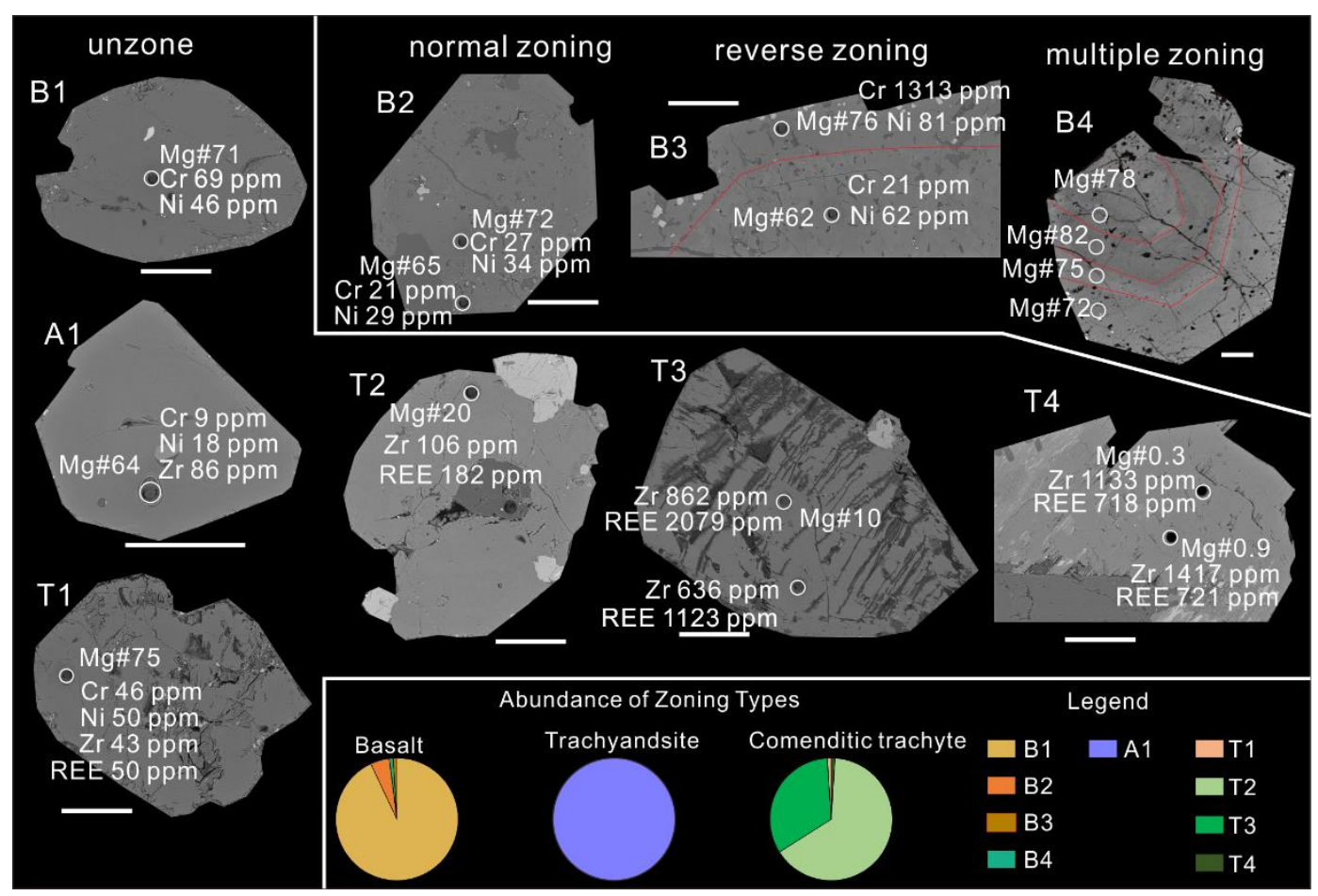

Figure 3. BSE images of selected clinopyroxene phenocrysts, highlighting different geochemical characteristics and zoning types. Pie charts show the relative proportion of each clinopyroxene type within different lithology. Scale bars are $200 \mu \mathrm{m}$.

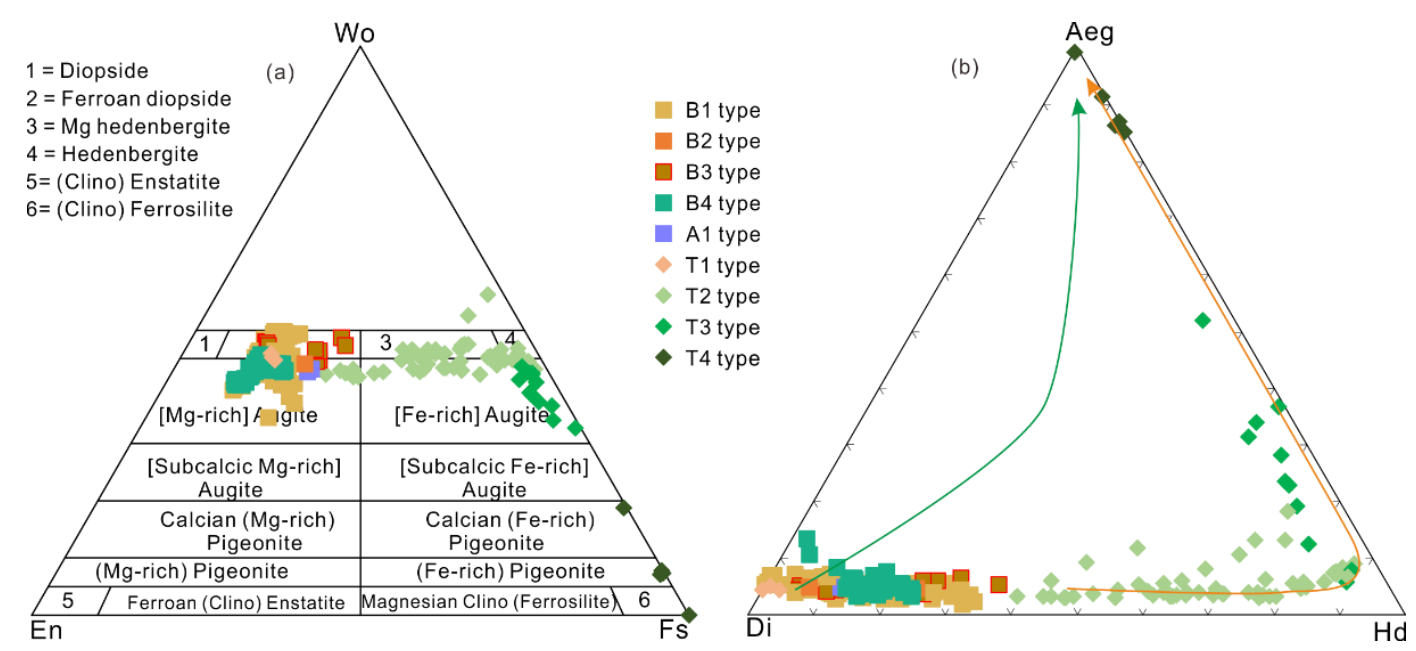

Figure 4. Clinopyroxene compositions plotted into the ternary (a)Wo-En-Fs system and (b)Aeg-Di-Hd system [32]. Some clinopyroxenes in the SSB from [24] and [28], clinopyroxene trends from other alkaline complexes are shown for comparison: green line [1] and orange line [33].

\subsection{Cpx in basalt}

Whilst the composition of B1 type clinopyroxenes in separate basalt are relatively homogeneous in perspective samples, the composition of clinopyroxenes varies widely in different basalt samples. The clinopyroxenes in Wangjiegang characterized by $\mathrm{Mg}^{\#}(72-82)$ and Wo39.7-49.7En36.6-49.3Fs10.6-14.9; the clinopyroxenes in Jiangbian characterized by Mg\# $^{\#}$ (6276) and Wo49.1-50.1En36.5-40.9Fs11.7-14.4; the clinopyroxenes in Zidong characterized by Mg\# (6973) and Wo34.7-49.6En34.6-46.8Fs13.7-18.5, and a basalt characterized by lower Mg $^{\#}$ value(62) and Wo43.3En35.2Fs21.5; the clinopyroxenes in Shitoucun characterized by Mg\# (69-76) and Wo32.345.8En39.5-43.1Fs13.5-16.7; the clinopyroxenes in jilixu characterized by $\mathrm{Mg}^{\#}$ (66-73) and Wo34.742.4En39.8-41.8Fs15.7-21.1. 

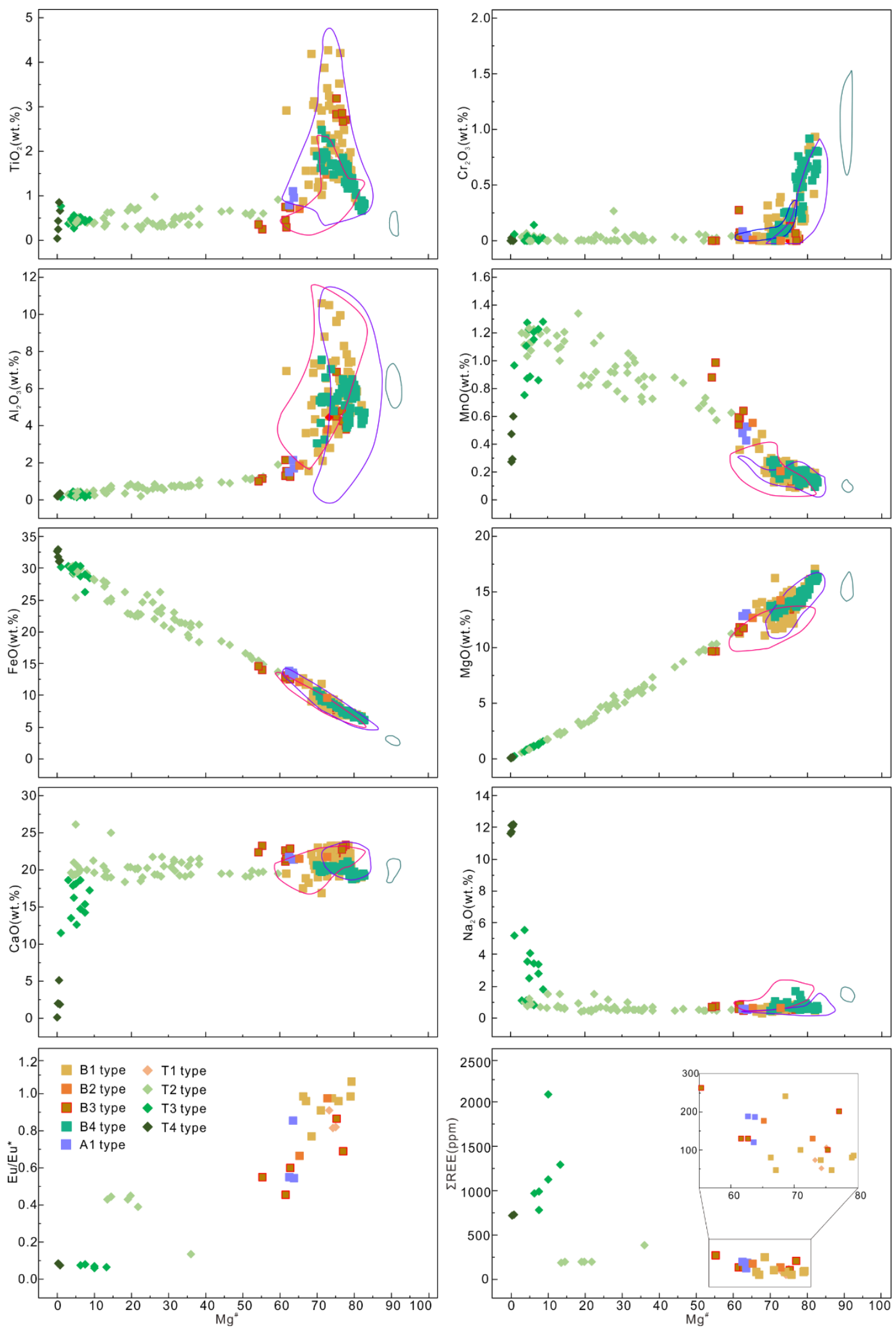

Figure 5. Major elements and REEs vs. Mg\# values in clinopyroxene from bimodal volcanic rocks in the SSB. The green solid line is the composition of clinopyroxenes in Hannuoba granulite (North China Craton) [34]; The pink solid line is the composition of clinopyroxenes in peridotite xenoliths in South China [34,36]; The purple solid line is clinopyroxenes in Hainan Cenozoic basalt are from [37]. Eu/Eu* $=\mathrm{EuN}_{N} /\left[\mathrm{Sm}_{\mathrm{N}}+\mathrm{GdN}\right]^{0.5}$, Normalising values are after [38]. 

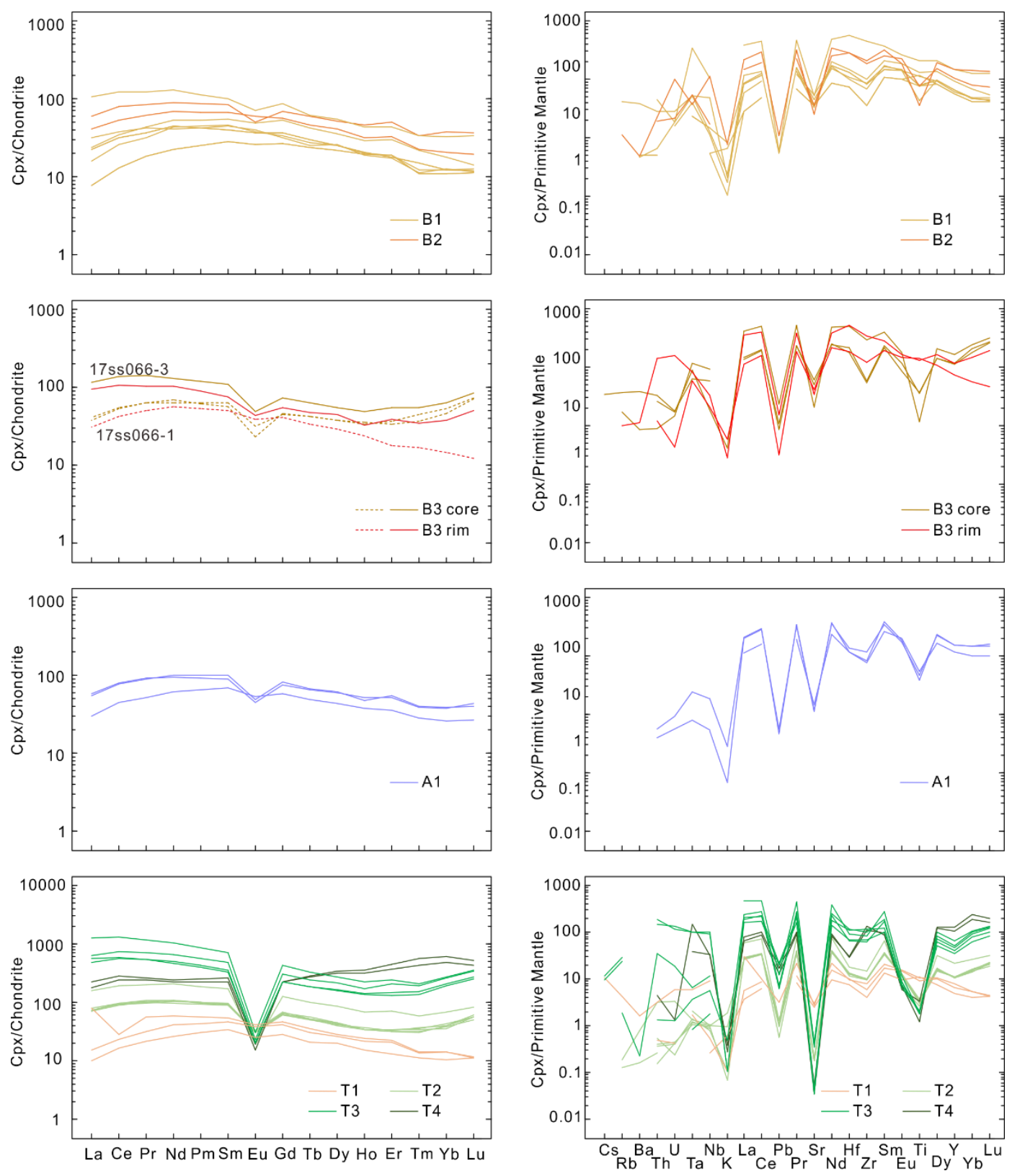

Figure 6. Chondrite-normalized REE distribution patterns and primitive mantle-normalized trace element distribution patterns for clinopyroxene from bimodal volcanic rocks in the SSB. Normalising values are after [38].

The trace elements content of clinopyroxenes in basalt varies significantly, and the normalized REE content indicates that they are enriched 8-100 times relative to the chondrite. The $\mathrm{Mg}^{\sharp}$ value of $\mathrm{B} 1$ type clinopyroxene has no obvious relationship with trace elements, the Cr content of clinopyroxene in 17ss066-1 sample can reach up to $2085 \mathrm{ppm}$, and the REEs contents are relatively homogeneous ( $\mathrm{REE}=43-99 \mathrm{ppm})$, exhibit no obvious Eu anomalies $\left(\mathrm{Eu} / \mathrm{Eu}^{*}=0.90-1.18\right.$, Fig.6a), and MREE enrichment relative to LREE and HREE $\left(\mathrm{LaN}_{\mathrm{N}} / \mathrm{NdN}_{\mathrm{N}}=0.34-0.82, \mathrm{~Tb}_{\mathrm{N}} / \mathrm{LuN}_{\mathrm{N}}=1.82-3.00\right.$, and $\left.\mathrm{LaN}_{\mathrm{N}} / \mathrm{Yb}_{\mathrm{N}}=0.71-2.53\right)$ in Chondrite-normalized REE distribution patterns (Fig. 6), reflecting different degrees of extraction from the mantle [34]. The clinopyroxene which has lower $\mathrm{Mg}^{\sharp}=62$, is characterized by lower $\mathrm{Eu} / \mathrm{Eu}^{*}=0.76$ and higher $\Sigma \mathrm{REE}=240 \mathrm{ppm}$.

B2 type clinopyroxenes have less abundant and are characterized by normal zoning. they can be observed in clinopyroxene in 18ss082-1 from Zidong, $\mathrm{Mg}^{\#}$ value decreases from core (73) to rim (65), and Wo44.5En40.6Fs14.9-Wo44.4En36.3Fs19.3. Compared with B1 type clinopyroxene, the core of B2 type clinopyroxene exhibited similar characteristics $\left(\mathrm{Eu} / \mathrm{Eu}^{*}=0.97, \Sigma \mathrm{REE}=129 \mathrm{ppm}\right)$, the rim of B2 type clinopyroxene exhibited strongly negative $\mathrm{Eu}$ anomalies $\left(\mathrm{Eu} / \mathrm{Eu}^{*}=0.66\right)$ and higher REEs content $(\Sigma \mathrm{REE}=176 \mathrm{ppm})$. 
B3 type clinopyroxenes have less abundant, occurs in Wangjiegang sample, and are characterized by reversed zoning. The green core of B3 type clinopyroxenes have lower $\mathrm{Mg}^{\#}$ value (55-62) and Wo44.7-48.6En28.2-34.4Fs19.7-23.8, the rim of B3 type clinopyroxenes have higher Mg value (76-78) and Wo47.4-49.0En38.5-40.5Fs11.3-12.4, which are similar to the B1 type clinopyroxenes of the same sample. Similar geochemical characteristics also can be observed in trace elements. The green core of B3 type clinopyroxenes exhibited strongly negative $\mathrm{Eu}$ anomalies $\left(\mathrm{Eu} / \mathrm{Eu}^{*}=0.54\right.$, Fig.6c $)$ and higher REEs content $(\Sigma \mathrm{REE}=263 \mathrm{ppm})$ than the $\operatorname{rim}\left(\mathrm{Eu} / \mathrm{Eu}^{*}=0.68\right.$, and $\left.\Sigma \mathrm{REE}=201 \mathrm{ppm}\right)$.

B4 type clinopyroxenes were not observed in this study. According to the study on clinopyroxene [24], there divided four zones from core to rim: the $\mathrm{Mg}^{\sharp}$ value in core range from 78 to 79 ; the $\mathrm{Mg}^{\sharp}$ value in core range from 80 to 83 ; the $\mathrm{Mg}^{\sharp}$ value in core range from 72 to 81 ; the $\mathrm{Mg}^{\sharp}$ value in core range from 70 to 76 . Core and Zone 1 exhibited the characteristics of reversed zoning, and Zone 1, Zone 2 and rim exhibited the characteristics of normal zoning.

\subsection{Cpx in trachyandesite}

The compositions of A1 type clinopyroxene in trachyandesite are homogeneous and characterized by $\mathrm{Mg}^{\sharp}$ (63-64) and Wo34.7-49.6En34.6-46.8Fs13.7-18.5, $\Sigma$ REE=120-188 ppm, flat REEs distribution pattern ( $\left(\mathrm{LaN}_{\mathrm{N}} / \mathrm{Yb}_{\mathrm{N}}=1.18-1.54\right)$. There are obvious depletions in $\mathrm{Pb}, \mathrm{Sr}, \mathrm{P}$, and $\mathrm{K}$ with strongly negative Eu anomalies $\left(\mathrm{Eu} / \mathrm{Eu}^{*}=0.54-0.88\right.$, Fig.6e) in all A1 type clinopyroxene phenocrysts.

\subsection{Cpx in comenditic trachyte}

The compositions of clinopyroxenes in comenditic trachyte are relatively homogeneous, with no obvious zoning textures. Light yellow $\mathrm{T} 1$ type clinopyroxenes compositional range are Wo45.0-46.2 En 40.6-40.8 Fs13.1-14.4, with low Na contents ( $<0.05 \mathrm{apfu}$, apfu: atoms per formula unit), Light green T2 Type clinopyroxenes compositional range are W042.1-56.7 En2.6${ }_{34.3} \mathrm{Fs} 27.8-54.6$, with low Na contents $(<0.15 \mathrm{apfu})$, Green T3 type clinopyroxenes compositional range are Wo33.1-42.9Eno.8-4.7Fs54.1-66.2, with medium Na contents (0.20 -0.45 apfu), dark green $\mathrm{T} 4$ type clinopyroxenes are similar to aegirine and the compositional range are $\mathrm{Q}_{13.3-}$ 22.8Jd0.5-1.4Aeg76.4-86.0, with $\mathrm{Na}$ apfu $\approx 1$.

Similar to the major elements, the difference of trace elements in comenditic trachyte is also obvious. The content of incompatible elements in T1 type clinopyroxene to T3 type clinopyroxene is negatively correlated with $\mathrm{Mg}^{\sharp}$. The trace element composition of $\mathrm{T} 1$ type clinopyroxenes are similar to that of B1 type clinopyroxenes in basalt, which exhibit no significant $\mathrm{Eu}$ anomalies $\left(\mathrm{Eu} / \mathrm{Eu}^{*}=0.81-0.90\right.$, Fig.6g) and relatively low REEs contents ( $\Sigma R E E=50-106 \mathrm{ppm}$ ); The T2 type clinopyroxenes in 20ss17-3 characterized by significant Eu anomalies $\left(\mathrm{Eu} / \mathrm{Eu}^{*}=0.39-0.44\right.$, Fig.6a), high REEs contents $(\Sigma R E E=183-197 \mathrm{ppm})$ and LREE enrichment relative to HREE ( $\left.\mathrm{LaN}_{\mathrm{N}} / \mathrm{Yb}_{\mathrm{N}}=1.82-2.35\right)$, another $\mathrm{T} 2$ type clinopyroxene in 17ss054-1 exhibited similar REE patterns to that of 20ss017-3, but shows more evolution characteristics, with lower Eu anomalies $\left(\mathrm{Eu} / \mathrm{Eu}^{*}=0.13\right)$ and higher REEs content $(\Sigma \mathrm{REE}=$ 397 ppm). For T3 type clinopyroxenes, clinopyroxenes in different samples with similar REE patterns and significant $\mathrm{Eu}$ anomalies $\left(\mathrm{Eu} / \mathrm{Eu}^{*}=0.06-0.08\right.$, Fig.6a), have various REE contents. The REEs contents of T3 type clinopyroxenes in 17ss054-1 ranging 780-979 ppm are much lower in 16ss009-1 ranging 1123-2079 ppm. The aegirine compositional of T4 type clinopyroxenes have similar significant Eu anomalies $\left(\mathrm{Eu} / \mathrm{Eu}^{*}=0.07-0.08\right.$, Fig.6a) and lower REE contents $(\Sigma \mathrm{REE}=718-722 \mathrm{ppm})$ compared to T3 type clinopyroxenes. These clinopyroxenes are characterized by HREE enrichment relative to LREE ( $\mathrm{LaN}_{\mathrm{N}} / \mathrm{Yb}_{\mathrm{N}}=0.29$ $0.46)$, which is similar to aegirine in other alkaline volcanic series $[1,33]$.

\section{Discussion}

\subsection{Cpx-melt equilibrium}

The evolution of magma systems involves complex magma processes such as magma mixing, recharge, mush remobilization, fractional crystallization, and assimilation, which 
may be recorded in the compositional and structural features of clinopyroxene [1]. Three main types of crystal populations are commonly classified in magmatic systems, including autocryst, antecryst, and xenocryst $[8,11,15]$. Autocrysts crystallize from the last stage of melt, which are usually in equilibrium with their host melt; antecrysts are phases that did not crystallize from the host magma, but rather from the earlier stage of the same magma system [1,18,39]; while xenocrysts are trap from wall-rocks or mantle xenolith [8]. Since autocrysts are the only crystals in equilibrium with their host melt, they can be distinguished from antecryst and xenocryst by equilibrium testing, which is a prerequisite for the application of the clinopyroxene-melt thermobarometer calculation.

We use the whole-rock composition to represent the melt composition as the bimodal volcanic rocks in the SSB are all holocrystalline and lack other glass and melt inclusion components. Cpx-melt equilibrium conditions are calculated using the KdFe-Mg model [40]: cpx-liqKdFe-Mg $=0.28 \pm 0.08$. The equilibrium diagram (Fig. 7) shows that not all clinopyroxenes are in equilibrium with whole-rock compositions.

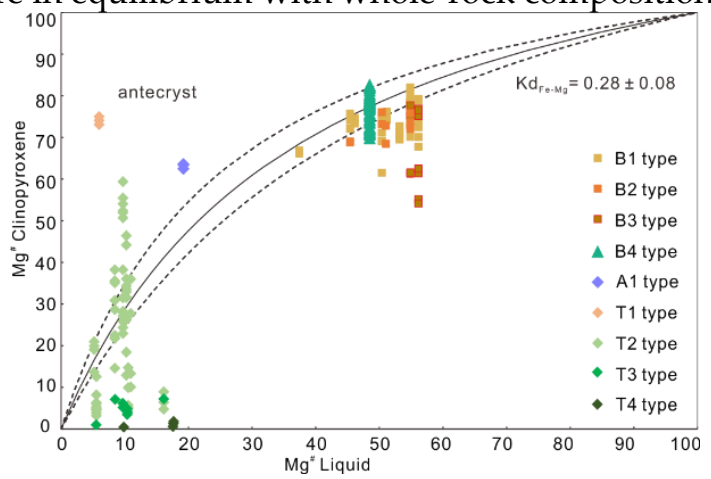

Figure 7. Equilibrium test diagram of clinopyroxene-melt. The bold and regular continuous lines define the equilibrium curves between clinopyroxene and melt.

The average $\mathrm{Kd}^{\mathrm{Fe}-\mathrm{Mg}}$ value of clinopyroxenes in basalt is 0.36 , and about $50 \%$ of clinopyroxenes, mainly B1, B2, and B4 type clinopyroxenes, can be identified as in equilibrium with their respective melt, while other disequilibrium clinopyroxenes show derived from more evolved magma with $\mathrm{Kd}^{\mathrm{Fe}-\mathrm{Mg}=} 0.36-0.61$. The green core $\mathrm{Kd}^{\mathrm{Fe}-\mathrm{Mg}}$ values of $\mathrm{B} 3$ type clinopyroxenes can up to 1.08 , and the rim $\mathrm{Kd}^{\mathrm{Fe}-\mathrm{Mg}}$ values of $\mathrm{B} 3$ type clinopyroxenes are

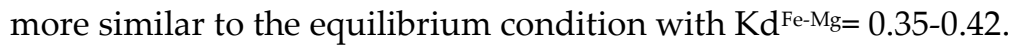

The average $\mathrm{Kd} \mathrm{d}^{\mathrm{Fe}} \mathrm{Mg}$ value of $\mathrm{A} 1$ type clinopyroxenes in trachyandesite is 0.14 , which suggests these clinopyroxenes prefer classified by antecryst which originated from basaltic magma, then ascend by the host magma into the shallow magma reservoirs.

The Kd $\mathrm{d}^{\mathrm{Fe}} \mathrm{Mg}$ values of clinopyroxenes in the comenditic trachyte are a wide variety, more than $2 / 3$ of clinopyroxenes are in disequilibrium with host melt. T1 type clinopyroxenes and some $\mathrm{T} 2$ type clinopyroxenes have obvious low $\mathrm{Kd}^{\mathrm{Fe}-\mathrm{Mg}}$ values and high $\mathrm{Mg}^{\sharp}$, these clinopyroxenes plotted above the equilibrium curve corresponding to the wholerock $\mathrm{Mg}^{\sharp}$, where the $\mathrm{Mg}^{\sharp}$ values of $\mathrm{T} 1$ type clinopyroxenes are up to 75 , showing obvious antecryst characteristics. The part T2 type clinopyroxenes with high $\mathrm{Mg}^{\sharp}=51-60$ are usually trapped in alkali feldspar phenocryst, which also reflects the character of crystallizing earlier than alkali feldspar phenocryst. The other $\mathrm{T} 2$ type clinopyroxenes below the equilibrium curve indicate derived from more evolved melts, and similar results occur in T3 type clinopyroxenes and T4 type clinopyroxenes (Fig. 7).

Overall, the morphologically diverse and mineral chemical clinopyroxenes reveal the complexity of the volcanic plumbing system beneath the SSB. The part B1, B4, and B2 type clinopyroxenes represent the autocryst crystal from the equilibrium host magma; the green core with low $\mathrm{Mg}^{\sharp}$ value and rim with high $\mathrm{Mg}^{\sharp}$ value in the B3 type clinopyroxenes reveal magma mixing, while the multi-phase zoning clinopyroxenes in the B4 type clinopyroxenes indicates the existence of magma recharge by other components[24]; the A1 type clinopyroxenes in trachyandesite, $\mathrm{T} 1$, and part $\mathrm{T} 2$ type clinopyroxenes in comenditic trachyte are antecrysts represent magma recharge and mixing, derived from early magma; 
those B1, B2, T2, T3, and T4 type clinopyroxenes below the equilibrium curve with their host melt may represent crystal settling and convection from a more evolved magma during the continuous fractional crystallization.

\subsection{Calculate P-T condition}

One of the main objectives of volcanic petrological studies is reconstruct the depth of magma pre-eruption [41], many single clinopyroxene and clinopyroxenes-equilibrium melt geothermometers have been established in earlier studies, and the pressures calculated by clinopyroxenes-equilibrium melt can represent magma reservoir depths, which have been widely used in volcanic studies to constrain magma ascent and storage condition. The temperature and pressure calculations for clinopyroxenes in basalt which in equilibrium with respective melt based on the Eqs. 30 and 33 [40], where the estimated average water content in basalt is $1.9 \%$ based on Perinelli model [42]; while for those disequilibrium clinopyroxenes calculated according to Eqs.32b and 32d [40]. In the comenditic trachyte, the temperature and pressure calculations of equilibrium clinopyroxenes based on the Masotta model [43], with an initial water content of $4 \mathrm{wt} . \%$. The crystallization conditions of T3 and T4 type clinopyroxenes have not been obtained as not yet applicable thermobarometer for disequilibrium clinopyroxenes, we speculate that these high evolution clinopyroxenes crystallize under a lower temperature and pressure conditions combined with their genesis.

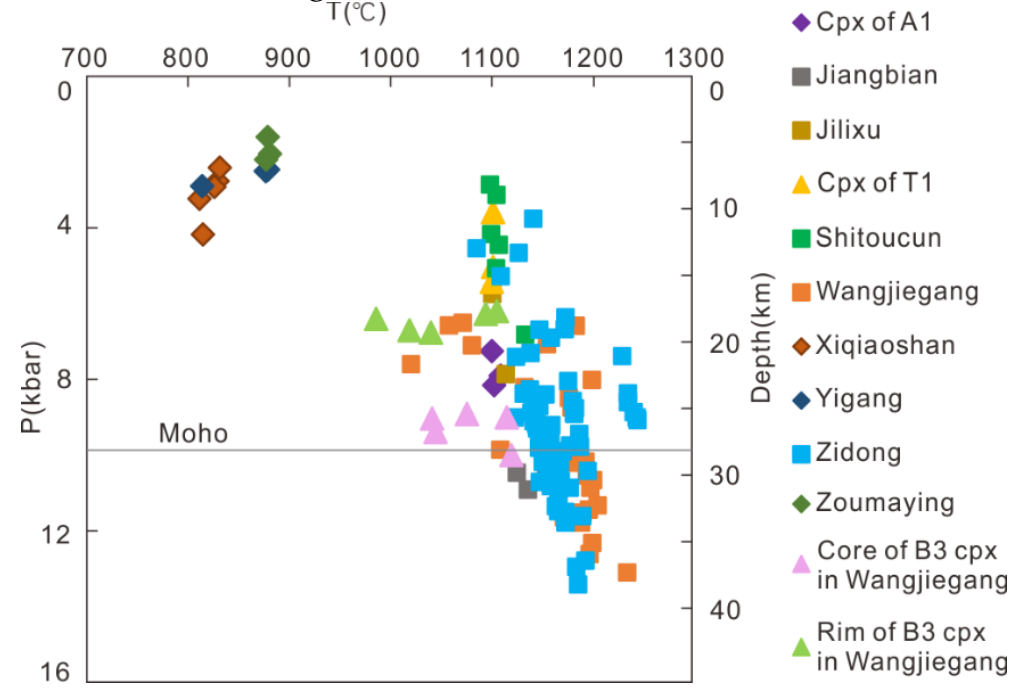

Figure 8. Temperatures and depths of crystallization of clinopyroxene phenocrysts in the bimodal volcanic rocks, calculated result using the clinopyroxene-liquid thermobarometer of Putirka [40] and Masotta [43] Pressure to depth conversion is assumed to be $2.8 \mathrm{~km} / \mathrm{kbar}[44]$.

The thermobarometric calculations are shown in the Table S2 and Fig. 8, in which clinopyroxene in basalt from Wangjiegang, Zidong and Jiangbian estimated average crystal pressure of $9.4 \mathrm{kbar}$ and temperatures $1158^{\circ} \mathrm{C}, \mathrm{n}=104$, green core of $\mathrm{B} 3$ type clinopyroxenes from Wangjieigang basalt estimated average crystal pressure of $6.5 \mathrm{kbar}$ and temperatures $1048{ }^{\circ} \mathrm{C}, \mathrm{n}=5$; clinopyroxenes from Jilixu basalt estimated average crystal pressure of $6.8 \mathrm{kbar}$ and temperatures $1106{ }^{\circ} \mathrm{C}, \mathrm{n}=2$; clinopyroxene from Shitoucun basalt estimated average crystal pressure of 4.4 kbar and temperatures $1107{ }^{\circ} \mathrm{C}, \mathrm{n}=6$; clinopyroxene in trachyandesite estimated average crystal pressure of $7.8 \mathrm{kbar}$ and temperatures $1103{ }^{\circ} \mathrm{C}, \mathrm{n}=3$; $\mathrm{T} 1$ type clinopyroxenes in comenditic trachyte estimated average crystal pressure of $4.7 \mathrm{kbar}$ and temperatures $1100^{\circ} \mathrm{C}, \mathrm{n}=3$; T2 type clinopyroxenes in Xiqiaoshan comenditic trachyte estimated average crystal pressure of $3.1 \mathrm{kbar}$ and temperatures 822 ${ }^{\circ} \mathrm{C}, \mathrm{n}=5$; $\mathrm{T} 2$ type clinopyroxenes in Zoumaying comenditic trachyte estimated average crystal pressure of $2.0 \mathrm{kbar}$ and temperatures $878{ }^{\circ} \mathrm{C}, \mathrm{n}=3$; T2 type clinopyroxenes in Yigang comenditic trachyte estimated average crystal pressure of $2.6 \mathrm{kbar}$ and temperatures $856{ }^{\circ} \mathrm{C}, \mathrm{n}=3$. The thermobarometric calculations show that clinopyroxene 
phenocrysts in the associated basalts of the SSB yield lower crystallization depths crystallize and distribute in the whole crust during the magma ascend. The estimated deepest crystallization depth of clinopyroxenes for basalt corresponds to depths of the lithospheric mantle, while the crystallization depth of clinopyroxenes in comenditic trachyte corresponds to depths of the upper crust.

\section{3. genesis of clinopyroxenes}

\subsection{1. genesis of $\mathrm{B} 1$ and $\mathrm{B} 2$ type clinopyroxenes}

The B1 and B2 type clinopyroxene is the most common type of basalt. Whilst the chemical composition is widely varied in different sample locations, the overall composition is relatively uniform, indicating crystallization in a relatively closed magma system. $\mathrm{B} 1$ and $\mathrm{B} 2$ type clinopyroxenes are characterized by lower $\mathrm{Mg}^{\#}$ and $\mathrm{Na} \mathrm{O}_{2} \mathrm{O}$ contents relative to clinopyroxenes from lherzolite xenolith (Fig. 4), higher Ti/Al ratio, and lower $\mathrm{Al}^{\mathrm{VI}}$ value relative to clinopyroxenes from granulite xenolith, which is close to the composition of volcanic clinopyroxene in basalt (Fig. 9).
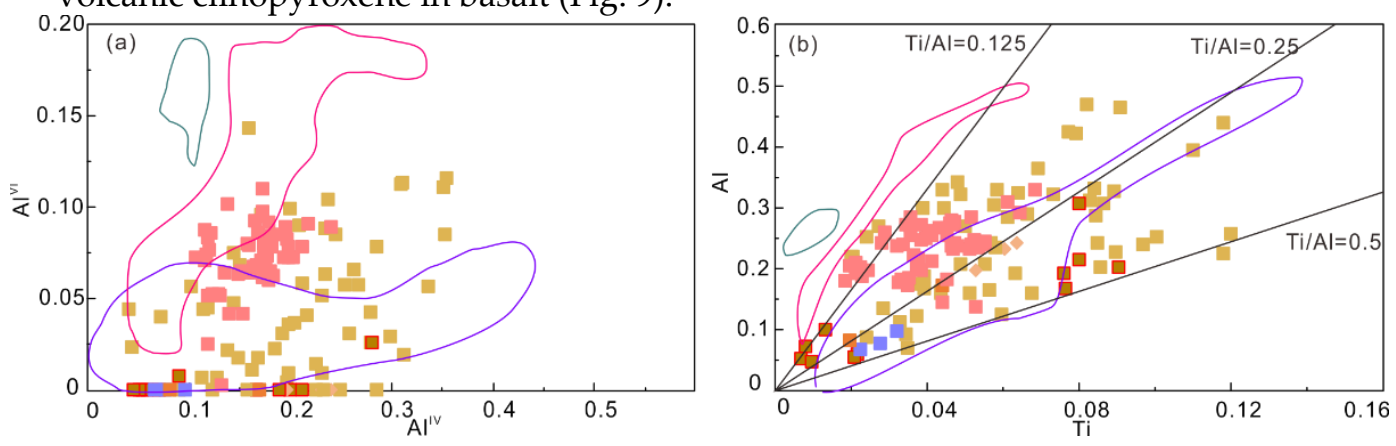

Figure 9. (a)Atomic proportion of $\mathrm{Al}^{\mathrm{VI}}$ v.s $\mathrm{Al}^{\mathrm{IV}}$ diagram in clinopyroxenes from basalt in the SSB. (b) Atomic proportion of Ti v.s Al diagram.

We calculated the REE compositions of the parental magma for the B1 type clinopyroxene host basalt using the mineral-melt partition coefficients determined by Hart and Dunn [45]. According to the melt composition calculated by inversion, similar enrichment of LREE and no obvious Eu anomaly can be observed compared with the whole rock composition. Among them, the whole rock composition of clinopyroxene is well-matched with the whole rock composition (17ss066-1, 19ss023-1, Fig.10a), indicating that clinopyroxenes are crystallized from the host magma, while some results (18ss082-1, 20ss025-1) are systematically horizontally distributed with the whole rock composition. The possible reason may be that the partitioning coefficient varies with the changes in melt composition, temperature, pressure, redox conditions, and other factors [9]. The results of B2 type clinopyroxene are similar to B1 type clinopyroxene.

\subsection{2. genesis of $\mathrm{B} 3$ type clinopyroxenes}

The B3 type clinopyroxenes are characteristic group of clinopyroxenes, even if they are rare and only occur in wangjiegang basalt samples. The geochemical composition shows obvious reverse zoning: green core characterized by Fe-rich, Mg-poor, high REE contents, and low $\mathrm{Eu}^{*} / \mathrm{Eu}$ values, and normal rim characterized by $\mathrm{Mg}$-rich, Fe-poor, low REE contents, and low $\mathrm{Eu}^{*} / \mathrm{Eu}$ values, which record an open magma system. Green core clinopyroxene, as a symbol of open magma system, has been widely studied [13,14,46,47]. The genesis of green core clinopyroxene mainly includes: (1) crystallization from a more evolution magma and subsequently mixed with mafic magma [8,14,47]; (2) Xenoliths from locally metasomatized upper mantle [48]; (3) Xenocrysts from the mantle, lower crust or wall-rocks [13,49]. 

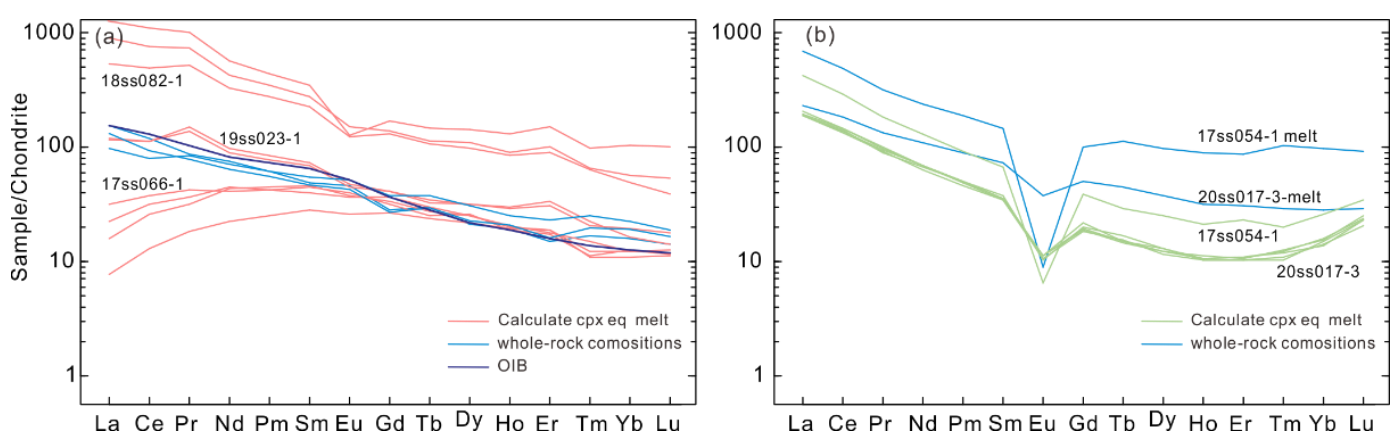

Figure 10. (a) Chondrite-normalized REE patterns for calculated melts of the basalt and comenditic trachyte in the SSB. The normalising values and OIB data are after [38]. The bulk rock data for the the basalt and comenditic trachyte are from [28].

According to the comparison of major and trace element composition of B3 type clinopyroxenes in basalts of the SSB and clinopyroxenes in lithospheric mantle peridotite of South China [34,36] and Hannuoba granulite of North China Craton [35], green core clinopyroxenes have different mineral chemical characteristics similar to B1 type clinopyroxenes. Therefore, the origin possibility of green core trapping from lithospheric mantle or lower crustal granulite can be excluded, and the resorption and sieved textures in green core of B3 type clinopyroxene indicates that the genesis of green core clinopyroxene is more inclined to (1) the results of magma mixing and magma recharge. The $\mathrm{Mg}^{\sharp}$ value in core and rim of B3 type clinopyroxene is negatively correlated with Ti and Al content, and positively correlated $\mathrm{Eu}$ anomalies, moreover their REE distribution patterns are also nearly parallel. Therefore, we propose that the green core of B3 type clinopyroxenes crystallizes from a more evolved melt at a shallow depth, and the rim of B3 type clinopyroxenes crystallizes from basaltic magma at a near equilibrium condition.

\subsection{3. genesis of B4 type clinopyroxenes}

No similar clinopyroxenes are found in this study. The B4 type clinopyroxene has clear boundary from the core, mantle, and rim, most analyzed points of the core and mantle zoning are in equilibrium with the whole rock composition, conversely in rim point. The points in zone 2 of the mantle are characterized by tholeiitic basalt origin, and the other three areas are characterized by alkaline basalt. Zidong basaltic magma begins to crystallize in alkaline basaltic magma, which is injected by tholeiitic magma to form zone 2 , and then continues to crystallize in alkaline basaltic magma to form zone 1 and rim [24].

\subsection{4. genesis of $\mathrm{A} 1$ and $\mathrm{T} 1$ type clinopyroxenes}

A1 type clinopyroxenes in trachyandesite and T1 type clinopyroxenes in comenditic trachyte are obvious antecrysts. Based on the distribution coefficient $\mathrm{Kd}=0.28$, calculated equilibrium melt with A1 type clinopyroxene, which $\mathrm{Mg}^{\#}$ value range 62 to 64 , has $\mathrm{Mg}^{\sharp}=32$, which is significantly higher than the whole rock $\mathrm{Mg}^{\sharp}$ value19. Similarly, calculated equilibrium melt with $\mathrm{T} 1$ type clinopyroxene has $\mathrm{Mg}^{\sharp}=45$, however, the $\mathrm{Mg}^{\sharp}$ of whole-rock is only 6 . In addition, the REE content of T1 type clinopyroxene and no obvious $\mathrm{Eu}$ anomalies are similar to the clinopyroxene in basalt, indicating derived from basaltic magma from deep depths.

\subsection{5. genesis of $\mathrm{T} 2$ and $\mathrm{T} 3$ type clinopyroxenes}

T2 type clinopyroxenes are the most abundant in comenditic trachyte, and the chemical compositions are also wide variable. As with the whole-rock compositions, T2 type clinopyroxenes exhibit significant negative $\mathrm{Eu}, \mathrm{Ti}$, and $\mathrm{Sr}$ anomalies in trace elements, which correlate with the unique partition coefficients of clinopyroxenes in alkaline melts [50]. Clinopyroxenes in alkaline magmatic systems are primitively calcic- in basaltic melts and become trend to sodic- during fractional crystallization [38]. Due to the lack of AlIV in $\mathrm{T} 2$ type clinopyroxenes, the addition of $\mathrm{Na}+$ atom is charge balance with $\mathrm{Fe} 3+$, as $\mathrm{Na}^{+}+$ $\mathrm{Fe}^{3+} \rightarrow 2 \mathrm{Ca}^{2+}$, the $\mathrm{REE}^{3+}$ incorporation becomes more favorable with the increase of $\mathrm{Fe} 3+$ by the substitution of $\mathrm{REE}^{3+} \rightarrow \mathrm{Fe}^{3+}$. In addition, Olin [51] proposes that elevated DHREE in 
Fe-rich clinopyroxenes reflects enhanced compatibility relative to LREE, as the HREE have ionic radii more similar to $\mathrm{Fe}^{2+}$ and $\mathrm{Mn}^{2+}$ in sixfold coordination than $\mathrm{Ca}^{2+}$ in eightfold coordination, and HREE incorporating in both eightfold coordination (substituting for $\mathrm{Na}$ or Ca in M2 site) and sixfold coordination (substituting for Fe and Mn in M1 or M2 site). This is consistent with the T2 type clinopyroxenes exhibiting a negative correlation between Fe, Mn v.s Mg\# (Fig. 5) and the enrichment of HREE [50,51].

Based on the partition coefficients [33], calculated the REE compositions of the parental magma for the T2 type clinopyroxenes exhibit higher REE contents, and the REE pattern parallel up to the host rock, suggesting that T2 type clinopyroxene in 17ss054-1 and 20ss017-3 may crystallize from the evolved magma (Fig. 10b).

The composition of T3 type clinopyroxenes are similar to T2 type clinopyroxenes with more obvious Eu, higher REE contents and parallel REE distribution pattern. All these chemical characteristics indicated T3 type clinopyroxenes are the results of the continuous evolution of $\mathrm{T} 2$ type clinopyroxenes.

\subsection{6. genesis of $\mathrm{T} 4$ type clinopyroxenes}

Different from other clinopyroxenes, the composition of T4 type clinopyroxenes trend to aegirine and may represent the terminal of clinopyroxene evolution (Fig. 4b), but the LREE and total REE in T4 type clinopyroxenes have lower content than T3 type clinopyroxenes.

This may be related to the unique incorporation mechanism of HREE and HFSE in the peralkaline system and the Na content in eightfold coordination (M2 site) of clinopyroxenes [52]. When $\mathrm{M}$ sites expand caused by Aeg content increasing, REE incorporation become less favorable, and when Aeg > 50(mol\%), although M sites shrink slightly, HREEs strongly incorporating in on sixfold coordination (M1 site), consistent with the increasing of HREE concentration observed in aegirine (Aeg > 80, $\mathrm{mol} \%$ ) in T4 type clinopyroxenes.

Aegirine is a rare phase in peralkaline rhyolitic volcanic rocks and occurs in temperature below $700{ }^{\circ} \mathrm{C}$ by experimental constrain $[53,54]$, while the crystallization temperature of comenditic trachyte(14ss003-5) exceeds $850^{\circ} \mathrm{C}$. In addition, there is little research on the partition coefficients of aegirine. The REE contents and HFSE contents in aegirine from the SSB are different from those aegirine in Romania [1] and Greenland [33], which have higher REE contents and lower Zr-Hf contents even all of these aegirine exhibit HREE enrichment relative LREE and $\mathrm{Zr}$-Hf positive anomalies. The genesis of aegirine should be constrain by further investigates.

\subsection{Fractional crystallization}

As described above, the clinopyroxenes in basalt have similar geochemical composition and REE pattern indicating that these clinopyroxenes crystallized from cogenetic magma, the clinopyroxenes in trachyandesite and T1, T2, and T3 type clinopyroxenes in comenditic trachyte have similar characteristics. Except for the obvious negative Eu anomalies, the A1, T1, T2, and T3 type clinopyroxenes in trachyandesite and comenditic trachyte have REE patterns parallel to those of clinopyroxenes in basalt, suggesting they crystallized from more evolved melts which evolution by basaltic magma. Combined with linear trends major elements of the clinopyroxenes in bimodal volcanic rocks, we propose that all clinopyroxenes may crystallize from cogenetic magmas and that the compositional differences among the clinopyroxenes were, in turn, caused by different degrees of mineral fractional crystallization during magma evolution.

We apply the Rayleigh fractionation equation: $\mathrm{C}_{\mathrm{L}}=\mathrm{C}_{\mathrm{i}} \times(1-\mathrm{F})^{(\mathrm{D}-1)}$ to model the trace element behavior in clinopyroxenes during fractional crystallization, where CL and Ci represent the trace element concentrations of the Liquid and initial melt with clinopyroxenes; $\mathrm{F}$ is the fractionation degree of the parental melt; $\mathrm{D}$ is the total partition coefficient based on the abundance and distribution coefficient of fractional phase. We select the equilibrium B1 type clinopyroxene in 17ss066-3 represent the primitive composition in basalt, which has higher $\mathrm{Mg}^{\sharp}$ value and lower REE contents, while the equilibrium T2 type clinopyroxene in 20ss017-3 in comenditic trachyte. According to the proportions of olive- clinopyroxene - plagioclase -apatite, which based on the mass balance calculate the result, 
20:10:68:2, we calculate the REE contents of clinopyroxene during fractional crystallization in basalt (Fig. 11a). However, the calculated results show LREE and HREE contents do not match with T2 type clinopyroxene, one reason of maybe clinopyroxenes in basalt inherits the characteristics of different degrees of extraction from the mantle [34]. The mass balance calculation based on above crystalline phase separation in the whole rock shows a better relationship between $17 \mathrm{ss} 066-3$ and 20ss017-3 ( $\mathrm{F}=0.75, r^{2}=0.53$ ) [55]. According to the alkaline feldspar-clinopyroxene-amphibole assemblage in a proportion of 80:10:10, except for the weaker Eu negative anomaly, other REE elements match well (Fig. 11a), indicating that $\mathrm{T} 3$ type clinopyroxenes are the results of the continuous evolution of T2 type clinopyroxenes in comeditic trachyte and followed by $\sim 80 \%$ crystallization, which corresponds to the Mass balance calculation of the whole rock $\left(\mathrm{F}=0.88, r^{2}=0.73\right)$ [55]. The results also explain that clinopyroxene phenocrysts haven't been observed in the comendite and pantellerite with more evolution, which may be related to the relatively heavy density of clinopyroxenes compared to the comenditic melt. During the comenditic and pantellertitc melt extraction process, the clinopyroxenes settle as density differentiation at the bottom of comenditic trachyte magma chamber and finally erupts with comenditic trachyte [14]. Moreover, compared with the phenocryst content of $8-15 \%$ in comenditic trachyte, the phenocryst content in comendite and pantellerite with the more evolution is characterized by poor crystal $(<5 \%)$ in petrography. In this study, we did not simulate the clinopyroxenes in trachyandesite, as these clinopyroxenes are in disequilibrium with the host rock.
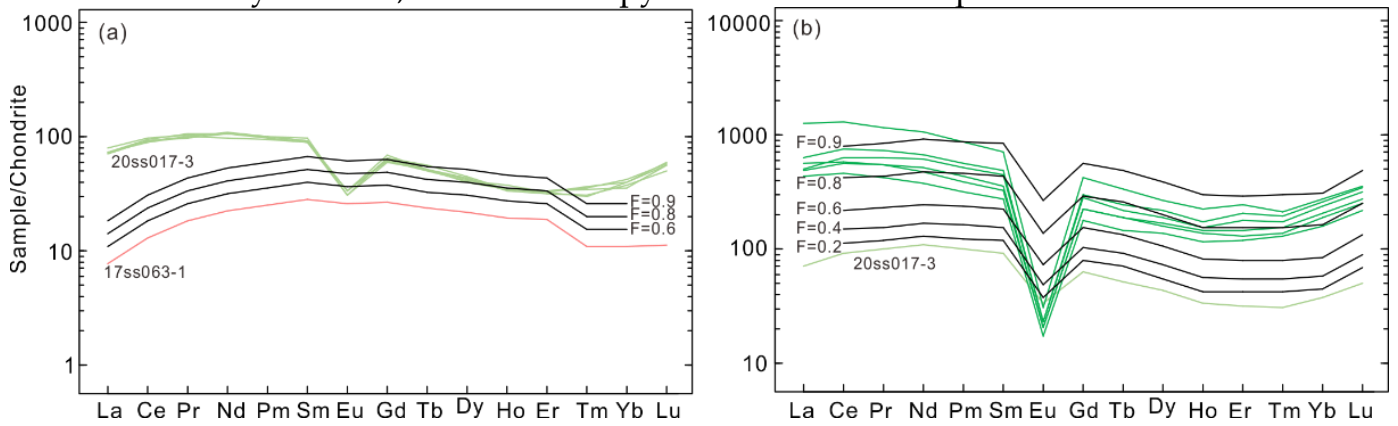

Figure 11. Inverse calculations of chondrite-normalized REE patterns of clinopyroxene produced by fractional crystallization. (a)based on the clinopyroxene from basalt compared with T2 type clinopyroxene from comenditic trachyte; (b)based on the T2 type clinopyroxene compared with T3 type clinopyroxene from comenditic trachyte. The evolution of these melts is modeled by variable proportion of fractional phases consist of olive, clinopyroxene, plagioclase, apatite, alkaline feldspar, and arfvedsonite and the partition coefficients are listed in Table S3.

\subsection{Magma plumbing system}

As described above, the texture and composition of clinopyroxene in bimodal volcanic rocks from the SSB record the complex magmatic process pre-eruption. The high abundance B1 and B2 type clinopyroxenes in basalt and T2 type clinopyroxenes in comenditic trachyte record the fractional crystallization during magma evolution; the reverse zoning in B3 and B4 type clinopyroxenes records magma mixing and recharge in the basaltic magma chamber, A1type clinopyroxene and T1 type clinopyroxene record that more evolved melt mixing with mafic melt, and the evolution degree of T3 and T4 type clinopyroxenes record crystal settling and convection.

It is worth noting that bimodal volcanic rocks in the SSB are mainly composed of felsic endmember, and in this volcano cluster dominated by felsic volcanic rocks, the basalt plays an important role in the magma evolution even with less voluminous: (1) the amount of basaltic magma, the volume of parental melts required for high fractional crystallization is $\sim 2.5-5$ times larger than the volume of felsic magma, especially the extremely fractional crystallization $(>90 \%)$ in the SSB [56]; (2) the physical property of basaltic magma, the viscosity and density is higher than the felsic volcanic rocks. As the consequence, the felsic magma reservoir is stored at shallow depth on the roof of the magma reservoir and formed a barrier to prevent the basaltic magma from reaching the surface directly; (3) the supply rate of basaltic magma. If the supply rate of basalt is too rapid to form peralkaline felsic magma, as rises rapidly to the surface to form basalt flow. A slower 
supply rate will provide parental material for fractional crystallization, and maintain the heat of the shallow magma reservoir, which is more conducive to the evolution of the peralkaline felsic magma chamber [57]. This equilibrium state is influenced and destroyed by the supply rate at any time, and the increased supply rete of basaltic magma may eventually trigger volcanic eruption.

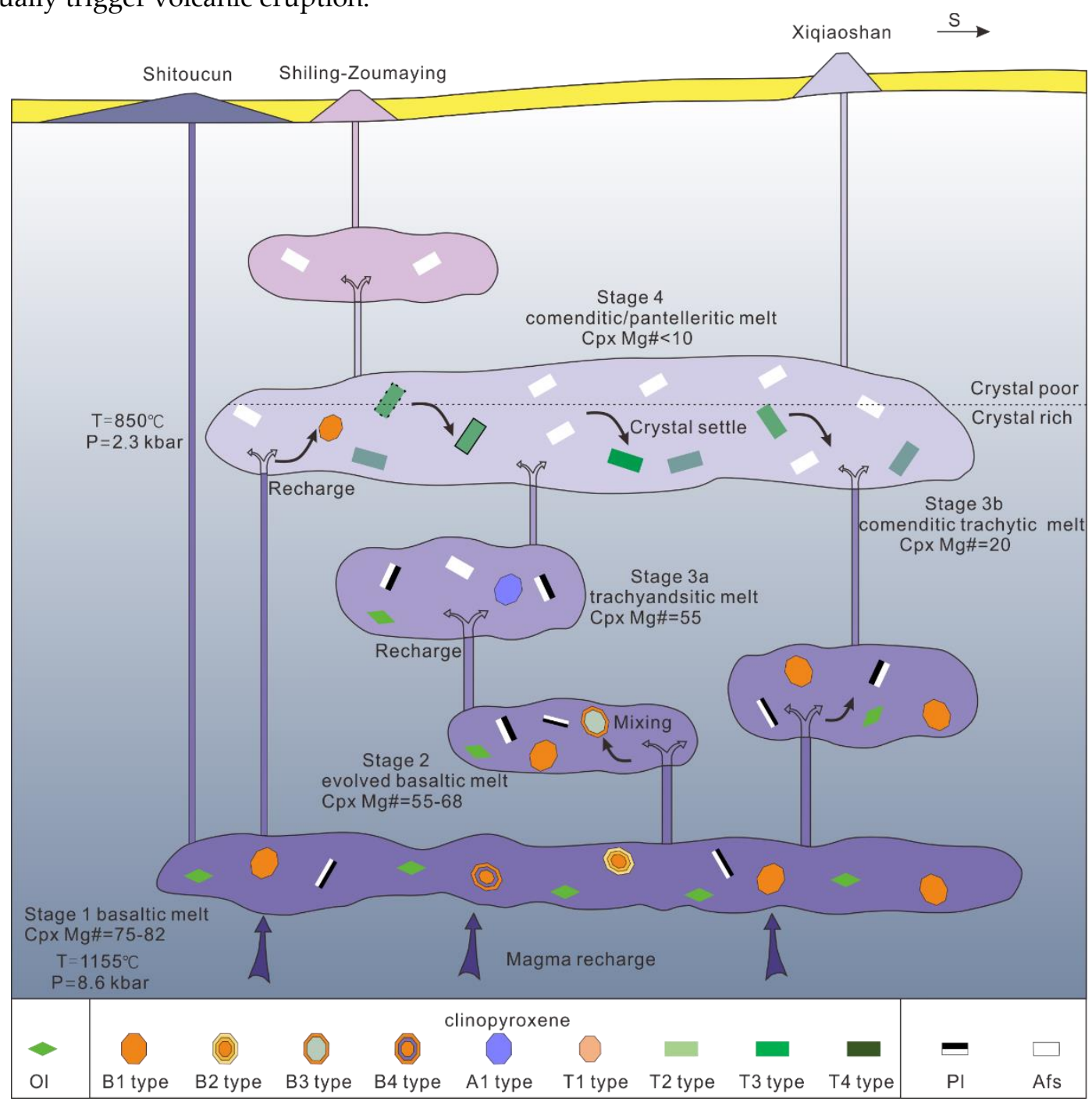

Figure 12. Schematic model of the magmatic processes of the alkaline magma system for the SSB.

Therefore, according to the thermobarometeric calculation, we reconstruct the magma plumbing system of the SSB (Fig. 12). The proposed magma plumbing system consists of a homogeneous source mantle and various evolved magma reservoirs reaching at different depths. Asthenospheric mantle-derived magmas undergo fractional crystallization below the Moho to form basalts beneath the SSB, and then ascend to the shallow depths form peralkaline felsic rocks by fractional crystallization or to the surface via cross lithospheric fault directly. Eventually, the peralkaline felsic rocks ascend to the surface via these conduits. Some evolved magma erupted to the surface through pipelines controlled by cross crustal faults to form volcanic rocks.

Stage1: mantle-derived magmas formed and stored at the lower crust and lithospheric mantle, rapid ascend to the surface in early eruption and crystallized phenocryst assemblage olivine -clinopyroxene (B1, B2 type) - plagioclase. With the decrease of liquidus, the clinopyroxenes are characterized by lower $\mathrm{Mg}^{\sharp}$ values, higher REE contents, and the more obvious Eu negative anomalies during fractional crystallization. 
Stage2: magma recharge characterized by primitive met with high $\mathrm{Mg}^{\sharp}$ and low REE content or mixing by tholeiitic melt into an evolved basaltic melt, forming the reverse zoning textures of B3 type clinopyroxenes and the B4 type clinopyroxenes in an open system.

Stage3: influenced by the supply rate of basaltic magma, basaltic magma evolved to felsic volcanic rocks at sallow depths by fractional crystallization after the early eruption. The source rock of felsic volcano is related to basaltic magma. It is formed by basaltic magma through continuous evolution and balanced crystallization of T2 type clinopyroxene. In this stage, $\mathrm{T} 2$ type clinopyroxenes crystallized from comenditic trachytic melt, with lower $\mathrm{Mg}^{\sharp}$ values, higher REE contents, and the more obvious Eu negative anomalies.

During the ascend of basaltic melt, existed primitive clinopyroxenes (A1 and T1 type clinopyroxenes) carried into trachyandesitic magma reservoir and comenditic trachytic reservoir, these primitive clinopyroxenes settled and formed the antecrysts.

Stage4: The evolved melt composition controls the chemical composition of clinopyroxenes in the shallow magma chamber. T3 type clinopyroxenes and T4 type clinopyroxenes (aegirine) are characterized by high $\mathrm{Fe}$, Na content, low $\mathrm{Mg}^{\sharp}$, and high REE contents. However, due to the crystal settling and convection, these clinopyroxenes settled to the bottom of comenditic trachytic magma reservoir and eventually erupts to the surface with comenditic trachyte.

\section{Conclusions}

The texture and composition of various clinopyroxenes in bimodal volcanic rocks from the SSB reveal the complexity of the deep magmatic process and the evolution history of magma ascend. Different clinopyroxene phenocrysts show magma processes in an open or closed system: fractional crystallization, magma mixing, recharge, and crystal settling. This study shows that detailed mineral-scale analysis is very important to reconstruct the complex volcano plumbing system.

(1) Clinopyroxenes in bimodal volcanic rocks from the SSB can be classified into 9 types according to their optical characteristics, major and trace element contents: four types in basalts, one type in trachyandesite, and four types in comenditic trachyte.

(2) With the evolution sequence of basalt - trachyandesite - comenditic trachyte comendite/pantellerite, while the clinopyroxenes exist an evolves sequence of diopside hedenbergite - aegirine, and characterized by the $\mathrm{Mg}^{\sharp}$ value and $\mathrm{Eu}^{*} / \mathrm{Eu}$ decreasing and REEs content increasing during magma evolution.

(3) The dominated abundant of B1, B2, T2 type clinopyroxenes involves crystallization differentiation in a closed- system. The reverse zoning of B3 type green core clinopyroxenes and the multiple zoning of B4 type clinopyroxenes are derived from the open system during magma evolution. The antecrysts consist of A1 and T1 type clinopyroxenes provide the evidence for magma mixing and magma recharge beneath the SSB.

(4) Thermobarometric calculations that clinopyroxenes in bimodal volcanic rocks from the SSB are distributed in the whole crust, basaltic magma reservoir is distributed in the lithospheric mantle $(\sim 40 \mathrm{~km})$ to upper crust $(\sim 10 \mathrm{~km})$, and comenditic trachyte reservoir is distributed in the upper crust $(5-10 \mathrm{~km})$.

Supplementary Materials: The following are available online at www.mdpi.com/xxx/s1. Table. S1 Electron microprobe analyses of clinopyroxenes and thermobarometric calculations based on Putirka [40] and Masotta et al. [43] model for the bimodal volcanic rocks in the SSB, Table. S2 LAICP-MS analyses of clinopyroxenes for the bimodal volcanic rocks in the SSB, Table. S3 Values of partition coefficients $(\mathrm{Kd})$ used in fractional crystallization modeling and the calculation of equilibrium melts.

Author Contributions: Conceptualization, P.C. and N.F.; methodology, P.C.; investigation, P.C. and X.Y.; resources, N.F.; writing-original draft preparation, P.C.; writing-review and editing, N.F. and X.Y.; visualization, N.F.; supervision, N.F.; project administration, N.F.; funding acquisition, N.F. All authors have read and agreed to the published version of the manuscript.

Funding: This research was funded by National Natural Science Foundation of China (No. 41572207). 
Data Availability Statement: Some of the data presented in this study are available in the Supplementary Materials, Tables S1-S3.

Acknowledgments: We are grateful to Xianqiu Zhang, Wei Zhang, Yu Zhang, Yang Liu, and Heping Sun for their help in the field and pervious works. We thank Hui Zhang for heip in EDS and BSE image at ECUT, Jinhua Hao for his help in EPMA at CUGB, Qian Wang for her help in LA-ICPMS at CAGS.

Conflicts of Interest: The authors declare no conflict of interest.

\section{References}

1. Batki, A.; Pál-Molnár, E.; Jankovics, M.É.; Kerr, A.C.; Kiss, B.; Markl, G.; Heincz, A.; Harangi, S. Insights into the evolution of an alkaline magmatic system: An in situ trace element study of clinopyroxenes from the Ditrău Alkaline Massif, Romania. Lithos 2018, 300-301, 51-71.

2. Coote, A.; Shane, P. Open-system magmatic behaviour beneath monogenetic volcanoes revealed by the geochemistry, texture and thermobarometry of clinopyroxene, Kaikohe-Bay of Islands volcanic field (New Zealand). J. Volcanol. Geoth. Res. 2018, 368, 51-62.

3. Rossi, S.; Petrelli, M.; Morgavi, D.; Vetere, F.P.; Almeev, R.R.; Astbury, R.L.; Perugini, D. Role of magma mixing in the preeruptive dynamics of the Aeolian Islands volcanoes (Southern Tyrrhenian Sea, Italy). Lithos 2019, 324-325, 165-179.

4. Perugini, D.; Poli, G. The mixing of magmas in plutonic and volcanic environments: Analogies and differences. Lithos 2012, 153, 261-277.

5. Streck, M.J.; Dungan, M.A.; Malavassi, E.; Reagan, M.K.; Bussy, F. The role of basalt replenishment in the generation of basaltic andesites of the ongoing activity at Arenal volcano, Costa Rica: evidence from clinopyroxene and spinel. B. Volcanol. 2002, 64, (5), 316-327.

6. Hughes, G.E.; Petrone, C.M.; Downes, H.; Varley, N.R.; Hammond, S.J. Mush remobilisation and mafic recharge: A study of the crystal cargo of the 2013-17 eruption at Volcán de Colima, Mexico. J. Volcanol. Geoth. Res. 2021, 416, 107296.

7. Nakagawa, M.; Wada, K.; Wood, C. Mixed magmas, mush chambers and eruption triggers: Evidence from zoned clinopyroxene phenocrysts in andesitic scoria from the 1995 eruptions of Ruapehu volcano, New Zealand. J. Petrol. 2002, 43, (12), $2279-2303$.

8. Streck, M.J. Mineral Textures and Zoning as Evidence for Open System Processes. Rev. Mineral. Geochem. 2008, 69, (1), 595-622.

9. Mollo, S.; Blundy, J.; Scarlato, P.; De Cristofaro, S.P.; Tecchiato, V.; Di Stefano, F.; Vetere, F.; Holtz, F.; Bachmann, O. An integrated P-T-H2O-lattice strain model to quantify the role of clinopyroxene fractionation on REE plus Y and HFSE patterns of mafic alkaline magmas: Application to eruptions at Mt. Etna. Earth-Sci. Rev. 2018, 185, 32-56.

10. Nazzareni, S.; Molin, G.; Peccerillo, A.; Zanazzi, P. Volcanological implications of crystal-chemical variations in clinopyroxenes from the Aeolian Arc, Southern Tyrrhenian Sea (Italy). B. Volcanol. 2001, 63, (1), 73-82.

11. Chen, L.; Zheng, Y.; Zhao, Z. Geochemical insights from clinopyroxene phenocrysts into the effect of magmatic processes on petrogenesis of intermediate volcanics. Lithos 2018, 316-317, 137-153.

12. Di Stefano, F.; Mollo, S.; Ubide, T.; Petrone, C.M.; Caulfield, J.; Scarlato, P.; Nazzari, M.; Andronico, D.; Del Bello, E. Mush cannibalism and disruption recorded by clinopyroxene phenocrysts at Stromboli volcano: New insights from recent 2003-2017 activity. Lithos 2020, 360 .

13. Jankovics, M.E.; Taracsak, Z.; Dobosi, G.; Embey-Isztin, A.; Batki, A.; Harangi, S.; Hauzenberger, C.A. Clinopyroxene with diverse origins in alkaline basalts from the western Pannonian Basin: Implications from trace element characteristics. Lithos 2016, $262,120-134$.

14. Leite De Oliveira, A.; Costa Dos Santos, A.; Nogueira, C.C.; Maia, T.M.; Geraldes, M.C. Green core clinopyroxenes from Martin Vaz Archipelago Plio-Pleistocenic alkaline rocks, South Atlantic Ocean, Brazil: A magma mixing and polybaric crystallization record. J. S. Am. Earth Sci. 2021, 105, 102951.

15. Li, X.; Zeng, Z.; Yang, H.; Zhao, Y.; Yin, X.; Wang, X.; Chen, S.; Qi, H.; Guo, K. Integrated major and trace element study of clinopyroxene in basic, intermediate and acidic volcanic rocks from the middle Okinawa Trough: Insights into petrogenesis and the influence of subduction component. Lithos 2020, 352-353, 105320.

16. Ovung, T.N.; Ray, J.; Ghosh, B.; Koeberl, C.; Topa, D.; Paul, M. Clinopyroxene composition of volcanics from the Manipur Ophiolite, Northeastern India: implications to geodynamic setting. Int. J. Earth Sci. 2018, 107, (4), 1215-1229.

17. Svetov, S.A.; Chazhengina, S.Y.; Stepanova, A.V. Geochemistry and Texture of Clinopyroxene Phenocrysts from Paleoproterozoic Picrobasalts, Karelian Craton, Fennoscandian Shield: Records of Magma Mixing Processes. Minerals-Basel 2020, 10, (5).

18. Ubide, T.; Gale, C.; Arranz, E.; Lago, M.; Larrea, P. Clinopyroxene and amphibole crystal populations in a lamprophyre sill from the Catalonian Coastal Ranges (NE Spain): A record of magma history and a window to mineral-melt partitioning. Lithos 2014, 184, 225-242.

19. Villaseca, C.; García Serrano, J.; Orejana, D. Pyroxenites and Megacrysts From Alkaline Melts of the Calatrava Volcanic Field (Central Spain): Inferences From Trace Element Geochemistry and Sr-Nd Isotope Composition. Front. Earth Sci. $2020,8$.

20. Welsch, B.; Hammer, J.; Baronnet, A.; Jacob, S.; Hellebrand, E.; Sinton, J. Clinopyroxene in postshield Haleakala ankaramite: 2. Texture, compositional zoning and supersaturation in the magma. Contrib. Mineral. Petr. 2016, 171, (1).

21. Zhu, B.; Wang, H.; Chen, Y.; Chang, X.; Hu, Y.; Xie, J. Geochronological and geochemical constraint on the Cenozoic extension of Cathaysian lithosphere and tectonic evolution of the border sea basins in East Asia. J. Asian Earth Sci. 2004, 24, (2), 163-175. 
22. Chung, S.; Cheng, H.; Jahn, B.; O'Reilly, S.Y.; Zhu, B. Major and trace element, and Sr-Nd isotope constraints on the origin of Paleogene volcanism in South China prior to the South China Sea opening. Lithos 1997, 40, (2), 203-220.

23. Zhou, H.; Xiao, L.; Dong, Y.; Wang, C.; Wang, F.; Ni, P. Geochemical and geochronological study of the Sanshui basin bimodal volcanic rock suite, China: Implications for basin dynamics in southeastern China. J. Asian Earth Sci. 2009, 34, (2), 178-189.

24. Zhang, W.; Fang, N.; Yuan, X.; Cui, L. Geochemical and Mineralogical Investigation on Different Types of Cenozoic Basalts in the Sanshui Basin: Implications for Magma Mixing Processes. J. Earth Sci-China 2019, 30, (4), 754-762.

25. Hou, M.; Ling, L.; Chen, H. Sedimentary and Tectonic evolution of Sanshui Basin, Guangdong Province. Geological Publishing House: Beijing, China, 2010; pp. 62-64(in chinese).

26. Zhang, X.; Zhou, X.; Chen, X. Division and correlation Atlas of Cretaceous-Tertiary drilling strata in Sanshui Basin. Ocean Press: Beijing, China, 1993; pp. 179(in Chinese).

27. Huang, H.; Guo, X.; Xia, S.; Qiu, X. Study of Crustal Thickness and Poisson's Ratio in the Coastal Area of South China. Chin. J. Geophys. 2014, 57, (6), 860-871.

28. Yuan, X. The record of cenozoic magmatism in Sanshui Basin and its relationship with the early tectonic evolution stage of the South China Sea. Ph.D, China University of Geosciences (Beijing), China, 2019.

29. Zhang, Y.; Fang, N. Source characteristics of basalts in Sanshui Basin and the early tectonic evolution stage of the South China Sea. Mar. Geol. Quat. Geol. 2021, 41, 95-113(in Chinese with English abstract).

30. Liu, Y.; Hu, Z.; Gao, S.; Günther, D.; Xu, J.; Gao, C.; Chen, H. In situ analysis of major and trace elements of anhydrous minerals by LA-ICP-MS without applying an internal standard. Chem. Geol. 2008, 257, (1), 34-43.

31. Liu, Y.; Hu, Z.; Zong, K.; Gao, C.; Gao, S.; Xu, J.; Chen, H. Reappraisement and refinement of zircon U-Pb isotope and trace element analyses by LA-ICP-MS. Chin. Sci. Bull. 2010, 55, (15), 1535-1546.

32. Morimoto, N.; Fabries, J.; Ferguson, A.K.; Ginzburg, I.V.; Ross, M.; Seifert, F.A.; Zussman, J.; Aoki, K.; Gottardi, G. Nomenclature of pyroxenes. Am. Mineral. 1988, 73, (9-10), 1123-1133.

33. Marks, M.; Halama, R.; Wenzel, T.; Markl, G. Trace element variations in clinopyroxene and amphibole from alkaline to peralkaline syenites and granites: implications for mineral-melt trace-element partitioning. Chem. Geol. 2004, 211, (3), 185-215.

34. Zhang, H.; Zheng, J.; Pan, S.; Lu, J.; Li, Y.; Xiang, L.; Lin, A. Compositions and processes of lithospheric mantle beneath the west Cathaysia block, southeast China. Lithos 2017, 286-287, 241-251.

35. Geng, X.; Liu, Y.; Zhang, W.; Wang, Z.; Hu, Z.; Zhou, L.; Liang, Z. The effect of host magma infiltration on the Pb isotopic systematics of lower crustal xenolith: An in-situ study from Hannuoba, North China. Lithos 2020, 366-367, 105556.

36. Zhang, H.; Zheng, J.; Lu, J.; Pan, S.; Zhao, Y.; Lin, A.; Xiang, L. Composition and evolution of the lithospheric mantle beneath the interior of the South China Block: insights from trace elements and water contents of peridotite xenoliths. Contrib. Mineral. Petr. 2018, 173, (7), 53.

37. Wang, X.; Li, Z.; Li, X.; Li, J.; Liu, Y.; Long, W.; Zhou, J.; Wang, F. Temperature, Pressure, and Composition of the Mantle Source Region of Late Cenozoic Basalts in Hainan Island, SE Asia: a Consequence of a Young Thermal Mantle Plume close to Subduction Zones? J. Petrol. 2012, 53, (1), 177-233.

38. Sun, S.S.; McDonough, W.F. Chemical and isotopic systematics of oceanic basalts: Implications for mantle composition and processes. In, 1989; Vol. 42.

39. Davidson, J.P.; Morgan, D.J.; Charlier, B.L.A.; Harlou, R.; Hora, J.M. Microsampling and Isotopic Analysis of Igneous Rocks: Implications for the Study of Magmatic Systems. Annu. Rev. Earth. Pl. Sc. 2007, 35, (1), 273-311.

40. Putirka, K.D. Thermometers and Barometers for Volcanic Systems. Rev. Mineral. Geochem. 2008, 69, (3) 61-120.

41. Kluegel, A.; Day, S.; Schmid, M.; Faria, B. Magma Plumbing During the 2014-2015 Eruption of Fogo (Cape Verde Islands). Front. Earth Sci. 2020, 8.

42. Perinelli, C.; Mollo, S.; Gaeta, M.; De Cristofaro, S.P.; Palladino, D.M.; Armienti, P.; Scarlato, P.; Putirka, K.D. An improved clinopyroxene-based hygrometer for Etnean magmas and implications for eruption triggering mechanisms. Am. Mineral. 2016, 101, (12), 2774-2777.

43. Masotta, M.; Mollo, S.; Freda, C.; Gaeta, M.; Moore, G. Clinopyroxene-liquid thermometers and barometers specific to alkaline differentiated magmas. Contrib. Mineral. Petr. 2013, 166, (6), 1545-1561.

44. Tao, Y.; Putirka, K.; Hu, R.; Li, C. The magma plumbing system of the Emeishan large igneous province and its role in basaltic magma differentiation in a continental setting. Am. Mineral. 2015, 100, (11-12), 2509-2517.

45. Hart, S.R.; Dunn, T. Experimental cpx/melt partitioning of 24 trace elements. Contrib. Mineral. Petr. 1993, 113, (1), 1-8.

46. Ziem À Bidias, L.A.; Chauhan, H.; Mekala, R.M.; Rao, N.V.C. Green core clinopyroxenes from basanites of Petpenoun volcanoes, Noun Plain, Cameroon volcanic line: chemistry and genesis. B. Volcanol. 2021, 83, (3), 13.

47. Neumann, E.R.; Wulff-Pedersen, E.; Simonsen, S.L.; Pearson, N.J.; Martí, J.; Mitjavila, J. Evidence for Fractional Crystallization of Periodically Refilled Magma Chambers in Tenerife, Canary Islands. J. Petrol. 1999, 40, (7), 1089-1123.

48. Pilet, S.; Hernandez, J.; Villemant, B. Evidence for high silicic melt circulation and metasomatic events in the mantle beneath alkaline provinces: the $\mathrm{Na}-\mathrm{Fe}$-augitic green-core pyroxenes in the Tertiary alkali basalts of the Cantal massif (French Massif Central). Miner. Petrol. 2002, 76, (1), 39-62.

49. Zhu, Y.; Ogasawara, Y. Clinopyroxene phenocrysts (with green salite cores) in trachybasalts: implications for two magma chambers under the Kokchetav UHP massif, North Kazakhstan. J. Asian Earth Sci. 2004, 22, (5), 517-527.

50. Baudouin, C.; France, L.; Boulanger, M.; Dalou, C.; Devidal, J. Trace element partitioning between clinopyroxene and alkaline magmas: parametrization and role of M1 site on HREE enrichment in clinopyroxenes. Contrib. Mineral. Petr. $2020,175,(5), 42$.

51. Olin, P.H.; Wolff, J.A. Rare earth and high field strength element partitioning between iron-rich clinopyroxenes and felsic liquids. Contrib. Mineral. Petr. 2010, 160, (5), 761-775. 
52. Bonechi, B.; Perinelli, C.; Gaeta, M. Clinopyroxene growth rates at high pressure: constraints on magma recharge of the deep reservoir of the Campi Flegrei Volcanic District (south Italy). B. Volcanol. 2019, 82, (1), 5.

53. Macdonald, R.; Bagiński, B.; Leat, P.T.; White, J.C.; Dzierżanowski, P. Mineral stability in peralkaline silicic rocks: Information from trachytes of the Menengai volcano, Kenya. Lithos 2011, 125, (1), 553-568.

54. Di Carlo, I.; Rotolo, S.G.; Scaillet, B.; Buccheri, V.; Pichavant, M. Phase Equilibrium Constraints on Pre-eruptive Conditions of Recent Felsic Explosive Volcanism at Pantelleria Island, Italy. J. Petrol. 2010, 51, (11), 2245-2276.

55. Chen, P.; Fang, N.; Wang, Z.; Yuan, X. Petrogenesis and tectonic implications of Eocene peralkaline felsic volcanic rocks from the Sanshui Basin, Southern China. Lithos (Under review)

56. Barker, S.J.; Wilson, C.J.N.; Baker, J.A.; Millet, M.A.; Rotella, M.D.; Wright, I.C.; Wysoczanski, R.J. Geochemistry and Petrogenesis of Silicic Magmas in the Intra-Oceanic Kermadec Arc. J. Petrol. 2013, 54, (2), 351-391.

57. Jeffery, A.J.; Gertisser, R.; Self, S.; Pimentel, A.; O'Driscoll, B.; Pacheco, J.M. Petrogenesis of the Peralkaline Ignimbrites of Terceira, Azores. J. Petrol. 2017, 58, (12), 2365-2401. 